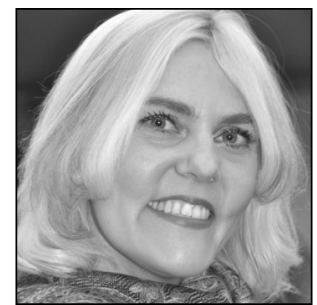

Julia Laffranque

Judge, Vice-President of the Second Section of the European Court of Human Rights Visiting Professor, University of Tartu

\title{
(Just) Give Me a Reason ....
}

The incentive for this paper was a recent judgment of the European Court of Human Rights (ECtHR, Strasbourg Court): Baydar v. the Netherlands. ${ }^{{ }^{2}}$ In this judgment, the Strasbourg Court addressed at length the interaction between its case law pertaining to, firstly, the requirement to give reasons for a refusal to refer a question to the Court of Justice of the European Union (CJEU, Luxembourg Court) and, secondly, the ECtHR's acceptance that a superior court may dismiss an appeal on the basis of summary reasoning.

This issue has bothered me for some time, in particular in relation to the legal system of my country of origin - Estonia. In Estonia, on the one hand, questions for a possible preliminary reference occasionally arise in complicated legal disputes before all levels of domestic courts, and, on the other hand, the Supreme Court can refuse leave to appeal (including in cases where the lower courts have decided not to refer a question to the Luxembourg Court), without real reasoning, using only one very laconic sentence. So far, the ECtHR has not yet dealt with the Estonian circumstances. ${ }^{*}$ This paper will, of course, avoid predictions of what the possible outcome of a respective case involving Estonia would be. However, the topic deserves, to my mind, general reflection, because it is not rare for a judicial system to face the dilemma of whether to prefer thorough expression of judicial reasoning always or to sacrifice the reasoning in order to have an effective leave-to-appeal system, which would allow the jurisdiction to concentrate on important matters with precedential value. In the present context, one should also not neglect the aspect of interplay between European Union (EU) law and the European Convention on Human Rights (ECHR), as well as the role of national courts finding their way in complex legal surroundings. Above all, it is about the parties of domestic litigation and their representatives who desire an answer as to why their national court has decided not to seek help from the CJEU and who also deserve their application being given due consideration within reasonable time.

1 'Just Give Me a Reason' is a song recorded by American singer and songwriter Pink. Judge Laffranque has previously too been inspired in the headings of her articles by famous song titles. See, for example, Julia Laffranque. Can't get just satisfaction. Anja Seibert-Fohr, Mark Villiger (eds). Judgments of the European Court of Human Rights - Effects and Implementation (Studies of the Max Planck Institute Luxembourg for International, European and Regulatory Procedural Law). Nomos 2014, pp. 75-114. - DOI: https://doi.org/10.5771/9783845259345_75. The current paper reflects only personal opinions of the author.

2 Baydar $v$. the Netherlands, No. 55385/14, 28.4 .2018 (not yet final).

3 It is not excluded that the ECtHR will need to deal with the issue; see the piece 'Tallinn water provider heads to human rights court in tariff dispute', by ERR, Estonia, 15.5.2018. Available at https://news.err.ee/831589/tallinn-water-provider-headsto-human-rights-court-in-tariff-dispute (most recently accessed on 29.6.2018). 


\section{Judicial reasoning and the interplay between European Union law and the European Convention on Human Rights}

Judicial reasoning refers both to the process by which a judge reaches a conclusion as to the appropriate result in a case and to the written explanation of that process in a published judgment. This paper uses and explores the latter of the meanings of judicial reasoning and concentrates on the issue of giving reasons in judicial decisions.

\subsection{The overall importance of giving judicial reasons}

\section{Reason to give reasons: The purpose of giving reasons}

For the judiciary, the modern state has always accepted that its judgments have to be underpinned by a proper and full justification: this principle is enshrined in most constitutions and is enforced by the highest courts. ${ }^{*}$

It goes without saying that it is important to give reasons for a judicial decision. Thanks to a presentation of reasoning, it is possible to understand why the judicial decision was made one way or another and, if available, seek appeal. ${ }^{*}$ Good reasoning helps also for acceptance of the judgment by the parties and by the society as a whole. According to the Strasbourg Court's case law, '[t]he accused's understanding of his conviction stems primarily from the reasons given in judicial decisions, [which is why] in such cases, the national courts must indicate with sufficient clarity the grounds on which they base their decisions. [...] Reasoned decisions also serve the purpose of demonstrating to the parties that they have been truly heard, thereby contributing to a more willing acceptance of the decision on their part'. ${ }^{* 6}$

The principle of giving judicial reasons is also linked to the proper administration of justice: ${ }^{*} 7$ it obliges judges to base their reasoning on objective arguments, preserves the rights of the defence, and prevents arbitrariness by allowing possible bias on the part of the judge to be discerned. ${ }^{*}$

Furthermore, the reasons are an important aid for implementing a judgment, since a fair trial has been fully respected only if the judgment is enforceable and will indeed be implemented.

The duty to give reasons in the Strasbourg and Luxembourg courts and in their case law

As far as the ECtHR is concerned, Article 45 ECHR states that reasons shall be given for judgments as well as for decisions declaring applications admissible or inadmissible. The Rules of the Court specify this requirement in detail. ${ }^{*} 9$

In the EU, Article 36 of Protocol No. 3 to the Treaty on the Functioning of the European Union (TFEU), on the Statute of the Court of Justice of the European Union, provides that the CJEU's judgments shall state the reasons on which they are based. This is supported by the Rules of Procedure of the Luxembourg

4 See Ingrid Opdebeek, Stéphane De Somer. The duty to give reasons in the European legal area: A mechanism for transparent and accountable administrative decision-making? A comparison of Belgian, Dutch, French and EU administrative law. Rocznik Administracji Publicznej 2 (2016), pp. 97-148, on p. 97.

5 The reasons given must be such as to enable the parties to make effective use of any existing right of appeal (ECtHR, Hirvisaari $v$. Finland, No. 49684/99, 27.9.2001). National courts should indicate with sufficient clarity the grounds on which they base their decision, so as to allow a litigant usefully to exercise any available right of appeal (Hadjianastassiou v. Greece, No. 12945/87, 16.12.1992).

6 Taxquet $v$. Belgium, No. 926/05, 16.11.2010.

7 Papon v. France (dec.), No. 54210/00, 25.7.2002.

8 Cerovšek and Božičnik v. Slovenia, Nos 68939/12 and 68949/12, 7.3.2017. As the Strasbourg Court has often noted, the rule of law and the avoidance of arbitrary power are principles underlying the ECHR. In the judicial sphere, those principles serve to foster public confidence in an objective and transparent justice system, one of the foundations of a democratic society. See, among many other authorities, mutatis mutandis, Roche $v$. the United Kingdom [GC], No. 32555/96, ECHR 2005-X, 19.10.2005.

9 See Rules of the ECtHR: Rule $56^{2}, 74^{1}, 87^{4}$. 
Court. ${ }^{*}{ }^{10}$ Provisions similar to those requiring the CJEU to give reasons are enshrined in the laws of Member States.

Both the ECtHR and the CJEU have interpreted Article 6 ECHR (on the right to a fair trial), as well as, respectively, Article 47 of the Charter of Fundamental Rights of the European Union (the Charter), on the right to an effective remedy and to a fair trial, to include the duty to give reasons. This is an important requirement in order to guarantee procedural justice. The case law of the ECtHR regarding the duty to give reasons will be elaborated upon below (in Subsection 2.1). In EU law, it is related mostly to the decisions of the institutions of the EU, as well as to the administrative decisions of the Member States. According to the explanations related to the Charter: Article 47 of the Charter applies to the institutions of the EU and to the Member States when they are implementing EU law and does so for all rights guaranteed by EU law. For example, according to the case law of the CJEU, Article 47 of the Charter requires that the person concerned be able to ascertain the reasons upon which the decision taken in relation to him is based, either by reading the decision itself or by requesting and obtaining disclosure of those reasons. ${ }^{*} 1$

\section{Judicial reasoning and authority of courts}

Judicial reasoning is also important for creating and maintaining the authority of courts. The formal invocation of the duty to give reasons both stems from and reinforces the perception that judicial authority and judicial reasons are interdependent. ${ }^{*}$

Even though the guarantee of reasoned judgments is taken for granted by many nowadays, it is remarkable that the topic is still regularly debated. ${ }^{*} 13$

\subsection{Don't want to be all by myself: Reasoning when asking for judicial help}

\section{The different roles of domestic and European courts}

The national courts can be regarded as the 'guardians of specialised national law', ${ }^{14}$ who rule on issues of breaches of domestic law. The CJEU, in turn, can be seen as the 'guardian of EU law', who ensures legal unity within the EU and autonomy of the EU law, and the ECtHR as 'conscience of Europe', who guarantees the respect, application, and interpretation of human rights invested in the ECHR. Each of them act in their sphere of competence. Yet none of them can live all by themselves. The Strasbourg Court and the Luxembourg Court, despite their fundamental differences ${ }^{*}{ }^{15}$, shall not adjudicate in isolation from each other and definitely must not do so separated from the national jurisdictions, which form an epicentre for this European interaction. National judges apply more and more ECHR and, of course, EU law, which has become an essential part of the Member States' national law. This interaction makes a dialogue between national courts and the CJEU/ECtHR vital. A brilliant institution of preliminary references anchors this dialogue on EU level. In EU law (via preliminary references; Article 267 TFEU) and also within the legal space of the ECHR (via advisory opinions; Protocol No 16, due to enter into force in August 2018) ${ }^{* 16}$, the

10 See also Article 87 of the Rules of Procedure of the CJEU, according to which the judgment shall contain the grounds for the decision.

11 Kadi II, C-584/10 P, C-593/10 P, and C-595/10 P, EU:C:2013:518, paragraphs 97-100.

12 Vlad Perju. Reason and authority in the European Court of Justice. - Virginia Journal of International Law 49 (2009) / 2 , pp. 308-377 (Boston College Law School Legal Studies Research Paper No. 170), on p. 322. Available also from SSRN, via https://ssrn.com/abstract=1324333 (most recently accessed on 5.5.2018).

13 E.g., Maurice Adams. De argumentatieve en motiveringspraktijk van hoogste gerechtshoven: rechtsvergelijkende beschouwingen ['Argumentation and reasoning practice of the Supreme Court: Comparative law considerations']. - Rechtskundig Weekblad 72 (2009) / 36, pp. 1498-1511; Vlad E. Perju (see Note 11).

14 See Katherina Paraschas. The role of the national judge and the preliminary ruling procedure. Available at http://www.eracomm.eu/oldoku/adiskri/12_jurisdictions/2011_03_paraschas_en.pdf (most recently accessed on 5.5.2018).

15 See Dean Spielmann, Panayotis Voyatzis. L'étendue du contrôle du respect des droits fondamentaux à l'aune de l'expérience judiciaire comparée ['The extent of the control over respect for fundamental rights featured in comparative judicial practice']. - Revue Trimestrielle Des Droits de l'Homme 2017/112, pp. 897-951, on p. 898.

16 Protocol No. 16 to the ECHR (STCE no. 214) enters into force on 1 August 2018 in respect of Albania, Armenia, Estonia, Finland, France, Georgia, Lithuania, San Marino, Slovenia, and Ukraine. 
national judge can ask for help from the European courts in order to have clarification about the EU law and, correspondingly, the ECHR.

\section{The duty to refer questions to the CJEU and exemptions from it}

In cases that involve EU law, the national courts, when they consider a decision by the CJEU necessary to enable them to pass judgment in the pending national case, seek, either on their own initiative or because of a duty, preliminary rulings from the CJEU. All national courts or tribunals against whose decisions there is no judicial remedy shall bring the matter before the CJEU (Article 267(3) TFEU). Exceptions to this duty can be made if the question is not relevant, in the sense that the answer to the question, regardless of what it might be, could in no way affect the outcome of the case; the question raised is materially identical to a question that has already been the subject of a preliminary ruling, in a similar case; or decisions of the CJEU have already dealt with the point of law in question, even though the questions at issue are not strictly identical. Exemption from the obligation to refer a matter to the CJEU can be made also if the correct application of EU law is so obvious as to 'leave no scope for any reasonable doubt as to the manner in which the question raised is to be resolved'. ${ }^{*} 7$ However, before it comes to the conclusion that such is the case, the national court or tribunal must be convinced that the matter is equally obvious to the courts of the other Member States and to the CJEU.

Most of the cases leading to a preliminary reference pertain to the proper interpretation of EU law. In addition, any national court that believes that a legal instrument adopted by the EU is invalid and does not want to apply this legal instrument is obliged to refer the matter to the CJEU, because the Luxembourg Court has an exclusive power to reject illegal provisions of EU law. ${ }^{*} 8$

Moreover, pursuant to interesting recent further developments in the case law of the CJEU, a national court of last instance is under an Article 267 TFEU obligation to refer a question to the CJEU for a preliminary ruling even if the constitutional court of its Member State has already assessed the constitutionality of national rules in light of regulatory parameters with content similar to rules under EU law. ${ }^{* 19}$ The CJEU considers the effectiveness of EU law to be in jeopardy otherwise. If the denial of leave to appeal by the firstinstance court is challenged, only the court that will rule on the appeal against denial of leave to appeal will be obliged to refer the case to the CJEU. ${ }^{20}$

Although there is at times an obligation to refer, one condition is that the case must be pending before a domestic court and the national court must believe that the referral is necessary to solve the case at hand. In this respect, the national court has its own margin of discretion, which is generally not subject to review. Namely, the CJEU usually does not scrutinise the need for referring questions to the CJEU, except where the question is not related to EU law or is of a hypothetical nature.

The CJEU has published Recommendations to national courts and tribunals in relation to the initiation of preliminary ruling proceedings. ${ }^{* 1}$

\section{The duty to give reasons when deciding upon referral}

The duty to give reasons, as far as the referral for preliminary ruling is concerned, comes into play from different angles. Habitually the national court is the master in the decision on whether to make a reference or not; however, it is not seldom that the parties of the domestic litigation make such a request. The CJEU has repeatedly stressed both in its Recommendations to national courts and in its case law that it is for the national court, not the parties to the main proceedings, to bring a matter before the CJEU. The right to determine the questions to be put to the CJEU in order to enable rendering judgment and the relevance of the questions it submits to the CJEU thus devolves on the national court alone, and the parties may not

17 C.I.L.F.I.T., C-283/81, E.C.R., 1982, 3415, para. 16 - the so-called acte clair doctrine.

18 Foto-Frost, Case 314/85, E.C.R., 1987, 4199.

19 Global Starnet, C-322/16, 20.12.2017, paras 21, 23-25. The case pertained to, among others, the principles of legal certainty and protection of legitimate expectations, which are common to EU law and to the constitutional frameworks of the Member States (in this case, Italy).

20 See Lyckeskog, C-99/00, 2002, 4.6.2002.

21 See the updated version of the Recommendations to national courts and tribunals in relation to the initiation of preliminaryruling proceedings, 2016/C-439/01, 25.11.2016. 
change their tenor. ${ }^{* 2}$ This is so because according to the CJEU the preliminary references institute direct co-operation between the CJEU and the national courts in order to ensure uniform interpretation of EU law and hence must be completely independent of any initiative by the parties. ${ }^{*}{ }^{23}$

Although the national court is not bound by requests of the parties, it should nevertheless articulate why it concludes that it will accept the request or not, and thus why it opts to refer or not to refer a case to the CJEU. In cases where the national court has a duty to refer but omits to do so, it should also state reasons for which it feels exempted from this duty. Finally, in cases where the national court decides to request the CJEU to interpret EU law, the requesting court in its reference for a preliminary ruling has to state why the interpretation is necessary to enable it to give judgment. In cases where the CJEU is requested to review the validity of EU law, the requesting court has to state why the legal instrument in question might be invalid.

Usually it is considered impossible to restrict the court's entitlement to refer cases to the CJEU by appealing the decision to refer a case to the CJEU if the case remains pending before the referring court. However, an appeal might be / should be possible if the court has failed to refer the case to the CJEU; EU law leaves this issue to be settled by national procedural law. The final courts avoiding making of a reference can lead to errors in application of EU law. ${ }^{*} 4$

\section{Consequences of non-referral in EU law}

Furthermore, infringement proceedings on EU level can be initiated against the Member State of the court concerned if the court had a duty to refer. ${ }^{*} 2$

Failure to refer can in turn lead also to state liability claims for judicial wrongs: ${ }^{* 26}$ in its decision in Köbler $^{* 27}$, the CJEU applied the principle of state liability (first laid down in Francovich ${ }^{* 28}$ ) and declared the possibility of an EU member state being held liable for decisions of its national courts adjudicating at last instance. The CJEU has further clarified the relevant principles in subsequent judgments. ${ }^{{ }^{2} 9}$

\section{The volume and importance of preliminary references and rulings}

According to the case law of the CJEU, the preliminary reference mechanism is based on the principle of sincere co-operation, established with a view to ensuring the proper application and uniform interpretation of EU law in all the Member States between national courts, in their capacity as courts responsible for the application of EU law, and the CJEU and to guaranteeing that individuals' rights under EU law are judicially protected. ${ }^{*} 30$ The obligation of final courts and of all courts with regard to validity issues to make

22 See the Recommendations to national courts and tribunals in relation to the initiation of preliminary-ruling proceedings, 2016/C-439/01, 25.11.2016, para. 3; György Katz v. István Roland Sós, C-404/07, CLI:EU:C:2008:553, 9.10.2008, para. 37.

24 See, for example, Ferreira da Silva, C-160/14, 9.9.2015.

25 I will elaborate in detail on neither the requirements to present reasoning for the refusal to make a reference for a preliminary ruling as reflected in the case law of the Luxembourg Court nor the problematic of whether the mere non-refusal to refer by a final court and thus non-obeisance to the duty to refer as such will constitute grounds for state liability or whether there has to be damage from this non-referral and a causal link between the non-referral and damages, with the ensuing problem of whether the applicants should domestically seek damages for failure to ask for a reference before turning to the Strasbourg Court (as it is not directly linked with the duty to give reasons, it is only to be noted that this is an issue that still requires development in ECtHR case law). For example, in the case Baydar $v$. the Netherlands, the Government of the Netherlands argued that the applicant had failed to exhaust all available domestic remedies by not bringing an action in tort against the state before the civil courts on the grounds that the Supreme Court's judgment was unlawful. According to the Government, since the alleged violation of Article 6 ECHR occurred at the very last stage of the criminal proceedings, no domestic court had had the opportunity to consider the applicant's claim that his rights under Article 6 ECHR had been violated by the Supreme Court's summary reasoning, which should, therefore, have been argued before the civil courts. The ECtHR, however, rejected this argument because the Government did not satisfy the Strasbourg Court - it did not refer to any domestic case law showing that the remedy was an effective one, available in theory and in practice at the relevant time (Baydar $v$. the Netherlands, No. 55385/14, 28.4.2018, para. 33).

26 See Rose D'Sa. Limits on suing an EU Member State for non-contractual damages for judicial errors made by a national court of last instance. - European Current Law 15 (2006) / November, pp. XI-XVI.

27 Köbler, C-224/01, E.C.R., 2003, I-10239.

28 Francovich, Bonifaci and Others, C-6 \& 9/90, E.C.R. 1991, I-5357.

29 See, for example, Traghetti del Mediterraneo SpA, C-173/03 [2006], 3 C.M.L.R.19.

30 C.I.L.F.I.T., C-283/81, E.C.R., 1982, 3415, para. 7. 
a referral before the CJEU is intended to prevent occurrence within the EU of divergences in judicial decisions on questions of EU law. The preliminary ruling given by the CJEU is binding on the referring national court as to the interpretation of the provision of EU law in question. But it often has an even wider impact, indirectly, on other cases. ${ }^{*} 31$ According to the annual report of the CJEU ${ }^{*} 2$ in 2017 , out of 739 new cases introduced to the Court, 533 were references for preliminary rulings, with courts from Germany, Italy, the Netherlands, Austria, and France in leading position. Out of 699 cases that were decided in that year, 447 were preliminary rulings. The average time for proceeding a case was 16.4 months and for urgent preliminary references 2.9 months. The tendency seems to be that also the constitutional courts of the Member States use more and more inter-judicial dialogue per preliminary reference (competitors collaborate) in order to smoothen what is described as 'interpretive competition'. ${ }^{*} 33$ It is also true that flexibility seems to be necessary in order to ensure healthy, lively judicial dialogue. ${ }^{*} 34$

It is a fact also that the preliminary rulings continue not only to be in quantity the main occupation of the CJEU but also to contribute actively to the further development of EU law.

\title{
The role of the Strasbourg Court in the dialogue between national courts and the CJEU
}

The duty to refer to the CJEU for a preliminary reference has relevance not only under EU law. It can also be regarded in light of the right to a fair trial (Article 6 ECHR). It has been correctly noted that the duty of last-instance national courts to submit preliminary references to the CJEU is analysed by academics almost exclusively in light of the Luxembourg Court's case law; however, the case law of the Strasbourg Court also appears to be relevant in this context. ${ }^{*} 35$ In several instances, the ECtHR was asked whether non-referral of preliminary questions to the CJEU constituted a breach of Article 6 ECHR, guaranteeing the right to a fair trial. One of the few existing analyses in this respect includes an attempt to demonstrate that the possibility of referring to the CJEU a preliminary reference is not interpreted in the same way by the CJEU, the ECtHR, and the national constitutional jurisdictions. ${ }^{*} 36$ The assumed differences in attitude open up interesting perspectives both for academics and for practitioners.

Let us now have a closer look at this interplay as seen from the Strasbourg Court's optic.

\section{The extent of judicial reasoning as interpreted and applied by the European Court of Human Rights and its effects on preliminary references in European Union law}

\subsection{The duty to give judicial reasons and its limits}

\author{
The scope of the duty to give reasons
}

The ECtHR imposes strict standards upon the Member States as regards the motivation of judgments in both civil and criminal cases. The guarantees enshrined in Article $6 \S 1$ ECHR include the obligation for domestic courts 'to indicate with sufficient clarity the grounds on which they base their decision'. ${ }^{37}$ It must be clear

31 This has also been acknowledged by the Strasbourg Court; see Laurus Invest Hungary KFT and Continental Holding Corporation $v$. Hungary and 5 other applications (dec.), No. 23265/13, 8.9.2015.

32 Rapport annuel: Panorama de l'Année, CJEU, 2017; 2017 Rapport Annuel. Activité Judiciaire, CJEU, 2017, pp. 108-109.

33 See Filippo Fontanelli, Giuseppe Martinico. Cooperative antagonists - the Italian Constitutional Court and the preliminary reference: Are we dealing with a turning point? (Eric Stein Working Paper No. 5/2008), pp. 21-22.

34 See Xavier Groussot. Spirit, are you there? - Reinforced judicial dialogue and the preliminary ruling procedure (Eric Stein Working Paper No. 4/2008), p. 24.

35 Agne Limante. Refusal to refer for a preliminary ruling and a right to a fair trial: Strasbourg court's position. Available at https://blogs.kcl.ac.uk/kslreuropeanlawblog/?p=1098\#.Wu3My5cuCUk (most recently accessed on 5.5.2018).

36 See Jirí Malenovský. Le renvoi préjudiciel perçu par trois Cours «souveraines» ['The preliminary references as perceived by the three sovereign jurisdictions']. - Journal de droit européen 2013, pp. 214-224.

37 H. v. Belgium, No. 8950/80, 30.11.1987; Karyagin, Matveyev and Korolev v. Russia, Nos 72839/01, 74124/01, and 15625/02, 28.5.2009; Hirvisaari v. Finland, No. 49684/99, 27.9.2001. 
from the decision that the essential issues of the case have been addressed. ${ }^{*} 38$ The duty to give reasons applies not only for judgments but also for major procedural decisions issued in the course of the proceedings, such as decision not to admit certain evidence or not to exempt the applicant from payment of a court fee. ${ }^{*} 39$

\section{Limits of the duty to give reasons}

As far as the limits of the requirement to give reasons is concerned, then the domestic courts have a certain margin of appreciation when choosing arguments and admitting evidence, although they are obliged to justify their activities by giving reasons for their decisions. ${ }^{*}{ }^{0}$ According to the interpretation of the ECtHR, Article 6 §1 ECHR does not require a detailed answer to every argument. ${ }^{*} 41$ The extent of the duty to give reasons varies according to the nature of the decision and is determined in light of the circumstances of the case, depending upon the diversity of submissions and differences existing in the Member States with regard to statutory provisions, customary rules, legal opinion, and the presentation and drafting of judgments. ${ }^{*}{ }^{2}$ However, the courts must examine litigants' main arguments, and, where a party's submission is decisive for the outcome of the case, they must give an express reply to these arguments. ${ }^{*} 43$ This extends also in particular to the rights and freedoms guaranteed by the ECHR and its Protocols, which the national courts are required to examine with particular care. ${ }^{*} 44$

The Strasbourg Court considered that the judge's retirement, which was allegedly the reason for her failure to provide written grounds, did not gave rise to exceptional circumstances as would justify a departure from the standard reasoning: since the date of the retirement of the judge had to have been known to her in advance, it should have been possible to take measures either for her to finish the applicants' case alone or to involve another judge at an earlier stage in the proceedings. ${ }^{*} 45$

When dismissing an appeal, an appellate court may simply endorse the reasons for the lower court's decision. ${ }^{*} 46$ Nevertheless, it has to address, whether itself or by endorsing the reasons of the lower court, the essential issues that were submitted to it, particularly in cases where the litigant has not been able to present his or her arguments orally. ${ }^{*} 47$ Appellate courts on second-instance level, which filter out unfounded appeals and have jurisdiction to deal with both facts and law, must give reasons for refusal to accept an appeal. ${ }^{*} 8$ It must be admitted, however, that the approach adopted at the national level differs considerably between Member States. Specific reasoning may be required in some systems, and more stereotyped reasoning may be permissible in others. ${ }^{*} 49$

\section{Acceptance of summary reasoning of supreme courts}

In the context of the current problematic it is important to note that, according to the case law of the ECtHR, Article $6 \S 1$ ECHR does not require a supreme court to give more detailed reasoning when it simply applies a specific legal provision to dismiss an appeal on points of law as having no prospects of success without further explanation. ${ }^{*}{ }^{0}$ In the case of an application for leave to appeal, the ECHR does not require that the rejection of leave be itself subject to a requirement to give detailed reasons. ${ }^{*} 51$

38 Boldea v. Romania, No. 19997/02, 15.2.2007.

39 Among others, see Suominen v. Finland, No. 37801/97, 1.7.2003; Múčková v. Slovakia, No. 21302/02, 13.6.2006.

40 Suominen v. Finland, No. 37801/97, 1.7.2003; Carmel Saliba v. Malta, No. 24221/13, 29.11.2016.

41 Van de Hurk v. the Netherlands, No. 16034/90, 19.4.1994; García Ruiz v. Spain [GC], No. 30544/96, 21.1.1999; Jahnke and Lenoble v. France (déc.), No. 40490/98, 29.8.2000; Perez v. France [GC], No. 47287/99, 12.2.2004.

42 Ruiz Torija $v$. Spain, No. 18390/91, 9.12.1994; Hiro Balani v. Spain, No. 18064/91, 9.12.1994.

43 Ruiz Torija v. Spain, No. 18390/91, 9.12.1994; Hiro Balani v. Spain, No. 18064/91, 9.12.1994; Buzescu v. Romania, No. 61302/002, 4.5.2005; Donadze v. Georgia, No. 74644/01, 7.3.2006.

44 Fabris v. France [GC], No. 16574/08, 7.2.2013; Wagner and J.M.W.L. v. Luxembourg, No. 76240/01, 28.6.2007.

45 Cerovšek and Božičnik v. Slovenia, Nos 68939/12 and 68949/12, 7.3.2017.

46 García Ruiz v. Spain [GC], No. 30544/96, 21.1.1999.

47 Helle v. Finland, No. 157/1996/776/977, 19.12.1997.

48 Hansen $v$. Norway, No. 15319/09, 2.10.2014.

49 See also in that respect the dissenting opinion of Judge Møse to the ECtHR judgment Hansen v. Norway, No. 15319/09, 2.10.2014.

$50 \quad$ Burg and Others $v$. France (dec.), No. 34763/02, 28.1.2003.

51 Kukkonen v. Finland no. 2, No. 47628/06, 13.1.2009; Bufferne v. France (dec.), No. 54367/00, 11.2.2003. 
The Strasbourg Court has accepted that a superior court may dismiss an application for appeal on the basis of summary reasoning. ${ }^{*}{ }^{2}$ The same approach is used with regard to constitutional court practice. ${ }^{*} 33$

\section{Reasoning and the jury}

Juries in criminal cases rarely give reasoned verdicts, and the relevance of this to fairness of a trial has been touched upon in a number of cases in front of the ECtHR. The Strasbourg Court has found that Article $6 \S 1$ ECHR does not require jurors to give reasons for their decisions; ${ }^{*} 54$ nevertheless, the accused, and indeed the public, must be able to understand the verdict, ${ }^{*} 55$ and it is also important that appeal rights be available to remedy any improper verdict by the jury. ${ }^{*} 6$ Since this question has not yet arisen in relation to EU law, it will not be further elaborated on in the current paper.

\subsection{Interaction between the duty to give reasons and acceptance of dismissing appeals with summary reasoning in the context of preliminary references}

\section{The ECtHR and EU law}

In general, as the EU is not (yet) a member of the ECHR, the current position of the Strasbourg Court with regard to EU law is based on cautious application of the principle of presumption of equivalent protection, which is reflected in already well-established case law. ${ }^{*} 57$ In Avotiňš v. Latvia ${ }^{*}{ }^{8}$, the Strasbourg Court has reiterated that, when applying EU law, the Contracting States remained bound by the obligations they had entered into on acceding to the ECHR and that those obligations were to be assessed in light of the presumption of equivalent protection established by the Court in 'Bosphorus Airways' $v$. Ireland'59 and developed in the Michaud $v$. France judgment. ${ }^{*} 60$ According to the Bosphorus case law, the states remain responsible under the ECHR for the measures they take to comply with obligations stemming from their membership of an international organisation to which they have transferred part of their sovereignty. However, the ECtHR also held in Bosphorus that action taken in compliance with such obligations is justified where the relevant organisation protects fundamental rights, as regards both the substantive guarantees and the mechanisms controlling their observance, in a manner that can be considered at least equivalent - 'comparable' - to that for which the ECHR provides. If such equivalent protection is provided by the organisation, the presumption is that a state has not departed from the requirements of the ECHR when it has implemented legal obligations flowing from its membership of the organisation. The equivalence may be subjected to review in light of any relevant change in fundamental rights' protection. In a recent judgment, O'Sullivan McCarthy Mussel Development Ltd $v$. Ireland ${ }^{*}$, the ECtHR found that, as the respondent state had not been wholly

52 See Wnuk v. Poland (dec.), No. 38308/05, 1.9.2009; Gorou v. Greece (no. 2) [GC], No. 12686/03, 20.3.2009; Talmane v. Latvia, No. 47938/07, 13.10.2016. See also Sale v. France, No. 39765/04, 21.3.2006; Burg and Others v. France (dec.), No. 34763/02, ECHR 2003 II.

53 See Wildgruber v. Germany (dec.), No. 32817/02, 16.10.2006.

54 Saric v. Denmark (dec.), No. 31913/96, 2.2.1999.

55 Taxquet v. Belgium [GC], No. 926/05, 16.10.2010; Legillon v. France, No. 53406/10, 10.1.2013.

56 Judge $v$. the United Kingdom (dec.), No. 35863/10, 8.2.2011.

57 Just to mention the most important of them: the Confédération Française Démocratique du Travail v. the European Communities, alternatively: their Member States a) jointly and b) severally decision of the European Commission of Human Rights of 10 July 1978; Etienne Tête v. France (dec.), No. 11123/84, 9.12.1987; Cantoni v. France, No. 17862/91, 15.11.1996; Matthews v. the United Kingdom, No. 24833/94, 18.2.1999; 'Bosphorus Airways'v. Ireland, No. 45036/98, 30.6.2005; Malik $v$. the United Kingdom, No. 23780/08, 13.3.2012. As to the admissibility of a case where infringement proceedings were introduced on EU level, see Karoussiotis v. Portugal, No. 23205/08, 1.2.2011. As to asylum-seekers (Dublin regulation), see M.S.S. v. Belgium and Greece, No. 30696/09, 21.1.2011; Tarakhel v. Switzerland [GC], No. 29217/12, 4.11.2014; A.M.E. $v$. the Netherlands (dec.), No. 51428/10, 13.1.2015. See also, with regard to child-abduction (Brussels II a regulation) and equivalent protection, Povse v. Austria (dec.), No. 3890/11, 18.6.2013, and, as to the European arrest warrant, Pianese $v$. Italy and the Netherlands (dec.), No. 14929/08, 27.9.2011; Pirozzi v. Belgium, No. 21055/11, 17.4.2018.

58 Avotiňšv Latvia [GC], No. 17502/07, 23.5.2016.

59 'Bosphorus Airways'v. Ireland, No. 45036/98, 30.6.2005.

60 Michaud v. France, No. 12323/11, 6.12.2012.

61 O’Sullivan McCarthy Mussel Development Ltd v. Ireland, No. 44460/16, 7.6.2018. 
deprived of a margin for manoeuvring with regard to how to achieve compliance with the relevant EU directive and the CJEU judgment; the Bosphorus presumption of equivalent protection did not apply.

\section{The ECtHR and preliminary references to the CJEU}

Just as did the CJEU in its famous judgment in the case Van Gend en Loos ${ }^{*} 62$, the ECtHR has stressed, in its judgment in the Bosphorus ${ }^{*} 63$ case, the importance of preliminary references as a cornerstone to guarantee the rights of individuals stemming from EU law.

The ECtHR's case law suggests that the CJEU should consider also Article 6 ECHR when interpreting the duty to refer a preliminary ruling request provided by Article 267(3) TFEU.

At the present stage, the Strasbourg Court does not deliberate on EU law when resolving questions related to the preliminary reference procedure and abstains from commenting on the EU rules or the CJEU's case law. In Lechouritou and Others $v$. Germany and other 26 Member States of the EU*64, the applicants were not satisfied with how the Luxembourg Court interpreted the Brussels Convention on civil matters. However, according to the Strasbourg Court, the EU institutions are experts in interpreting the EU law; the Luxembourg Court's reasoning was not arbitrary; and, therefore, the application was manifestly ill-founded. By principle, the Strasbourg Court does not find it necessary to examine the accordance of the national law with the EU law: it is primarily for the national authorities, notably the courts, to resolve issues of interpretation and application of domestic law including EU law aspects ${ }^{*} 65$, with the Strasbourg Court's role being confined to ascertaining whether the effects of such adjudication are compatible with the ECHR.

The ECtHR seems to fully acknowledge the exceptions to the obligatory preliminary references as developed by the CJEU. Nevertheless, the ECtHR emphasises the duty of last-instance national courts to provide justifications for refusal to refer a preliminary question to the CJEU. The ECtHR has observed that a domestic court's refusal to grant a referral may, in certain circumstances, infringe the fairness of proceedings where the refusal proves to have been arbitrary. Such a refusal may be deemed arbitrary in cases where the applicable rules allow no exception to the granting of a referral, where the refusal is based on reasons other than those provided for by the rules, or where the refusal was not duly explained. ${ }^{* 66}$

\section{Rationale of the Ullens de Schooten judgment}

The most famous judgment of the ECtHR pertaining to the final court's duty to give reasons for refusing a request for a preliminary ruling from the CJEU was made in the case Ullens de Schooten and Rezabek $v$. Belgium. ${ }^{*}{ }^{*}$ In this case the applicants complained about refusal to uphold their request for a question to be referred to the CJEU for a preliminary ruling by the highest courts (the Court of Cassation and Conseil d'État) in Belgium. The Strasbourg Court found no violation of Article 6 \$1 ECHR. The ECtHR stated that the ECHR does not guarantee as such a right for a case to be referred by a domestic judge to another jurisdiction, be it national or supranational jurisdiction. Therefore, while the ECtHR did not rule out a nonreferral, it is possible only if it is well-reasoned, if it is not arbitrary and if it does not constitute a violation of the ECHR. According to the Strasbourg Court, Article 6 §1 ECHR imposes, in this context, an obligation for domestic courts to give reasons, in light of the applicable law, for any decisions in which they refuse to refer a preliminary question, especially where the applicable law allows for such a refusal only on an exceptional basis. The Strasbourg Court fully acknowledged the C.I.L.F.I.T. case law of the CJEU and indirectly supported the CJEU's interpretation of the EU Treaties, thereby enforcing the obligation of final courts to ask for preliminary references from the CJEU.

Ullens de Schooten can be considered a balanced approach in favour of co-operation between the Strasbourg and Luxembourg courts. In applying the strict minimum of Article 6 §1 ECHR requirements, the

62 Van Gen den Loos, ECJ, Case 26/62, 5.2.1963, E.C.R. English special edition 1963, p. 3.

63 'Bosphorus Airways' v. Ireland, No. 45036/98, 30.6.2005.

64 Lechouritou and Others $v$. Germany and other 26 Member States of the EU, No. 37937/07, 3.4.2012.

65 See, for example, Ullens de Schooten and Rezabek v. Belgium, Nos 3989/07 and 38353/07, 20.9.2011, restated in Soros $v$. France, No. 50425/06, 6.10.2011 and more recently Delfi $v$. Estonia [GC], No. 64569/09, 16.6.2015.

66 Baydar v. the Netherlands, No. 55385/14, 28.4.2018, para. 39.

67 Ullens de Schooten and Rezabek v. Belgium, Nos 3989/07 and 38353/07, 20.9.2011. 
ECtHR, however, viewed the duty to give reasons as something not only reserved for the courts of last instance, thus going beyond its decision in the case John v. Germany. ${ }^{* 68}$

\section{Developments in the wake of Ullens de Schooten case law}

In its further decisions and judgments, the Strasbourg Court has followed its Ullens de Schooten et Rezabek case law and has found no violation of Article $6 \S 1$ ECHR because the decision not to refer has been sufficiently reasoned. ${ }^{*} 69$

In two decisions involving France, the ECtHR rejected the application because the applicants had not explicitly requested national administrative jurisdictions to refer questions to the CJEU*7o.

The case law of the Strasbourg Court emphasising the need for parties to have requested a referral has prompted an interesting debate. The critics of this reasoning have pointed out that two dangers emerge with the ECtHR approach: firstly, that it is contrary to the spirit of the preliminary references to bind the need to refer and the need to present reasons for a non-referral with the request of a party to refer and, secondly, that the ECtHR has introduced an additional condition to the Köbler case law. ${ }^{*}{ }^{1}$ However, one should keep in mind that the Strasbourg Court has a subsidiary role and adjudicates only after the domestic remedies have been exhausted; it can, as a guardian of fair trial, sanction in cases where the domestic courts have failed to respond to the request of the applicant for referral or where this response has been manifestly arbitrary. Otherwise the ECtHR would risk itself interpreting the EU law, if it were to judge whether the domestic court on its own initiative rightly refused to refer the case to the Luxembourg Court. It is not, however, the competence of the Strasbourg Court to judge the application of EU law on national level; the Strasbourg Court is there to remedy a violation of the ECHR, not of EU law. An application filed before the Strasbourg Court does not replace the mechanism that has been introduced by the Luxembourg Court with the Köbler case law. In this respect, one should also emphasise that there is no individual right to ask for referral of questions to the CJEU and that, according to EU law, the preliminary reference is not a subjective right but rather an effective instrument for dialogue between national courts and the CJEU, which of course serves to protect the rights of individuals.

The Strasbourg Court has held that where a request to obtain a preliminary ruling was insufficiently pleaded or where such a request was only formulated in broad or general terms, it is acceptable under Article 6 ECHR for national superior courts to dismiss the complaint by mere reference to the relevant legal provisions governing such complaints if the matter raises no fundamentally important legal issue or for lack of prospects of success without dealing explicitly with the request. ${ }^{*} 72$

Furthermore, in the case Stichting Mothers of Srebrenica and Others $v$. the Netherlands ${ }^{*} 73$, the Strasbourg Court found that the summary reasoning used by the Supreme Court to refuse a request for a preliminary ruling was sufficient, pointing out that it followed from a conclusion already reached with another part of the Supreme Court's judgment that a request to the CJEU for a preliminary ruling was redundant. In another case, the Court observed that the preliminary ruling requested by the applicant in that case would not have changed the conclusion reached by the Council of State of Greece, since his appeal had been declared inadmissible for reason of non-compliance with statutory requirements for the admissibility of appeal. ${ }^{*} 74$

In yet another case, Sindicatul Pro Asistenta Sociala $v$. Romania, ${ }^{*} 75$ the ECtHR did not find a violation of Article 6 \$1 ECHR, because the questions the applicants requested the national court to refer to the CJEU were not pertinent, such that the national court sufficiently motivated its refusal.

68 John v. Germany, No. 15073/03, 13.2.2007.

69 Vergauwen v. Belgium (dec.), No. 4832/04, 10.4.2012; Ferreira Santos v. Portugal (dec.), No. 30123/10, 4.9.2012.

70 Greneche and Others $v$. France (dec.), No. 34538/08, 15.10.2013; Ryon and Others $v$. France, No. 33014/08, 15.10.2013.

71 Jirí Malenovský (see Note 35).

72 See Wallishauser v. Austria (No. 2), No. 14497/06, 20.6.2013; see also Rutar Marketing D.O.O. v. Slovenia (dec.), No. 62020/11, 15.4.2014 and, already earlier, Moosbrugger v. Austria, No. 44861/98, 25.1.2000.

73 Stichting Mothers of Srebrenica and Others $v$. the Netherlands, No. 65542/12, 11.6.2013.

74 Astikos Kai Paratheristikos Oikodomikos Synetairismos Axiomatikon and Karagiorgos v. Greece (dec.), Nos 29382/16 and 489/17, 9.5.2017.

75 Sindicatul Pro Asistenta Sociala v. Romania (dec.), No. 24456/13, 6.3.2014. 


\section{Finding a violation of Article $6 \S 1$ ECHR for non-reasoning for non-referral}

However, in Dhahbi $v$. Italy ${ }^{*} 76$, the Strasbourg Court found a breach of Article $6 \S 1$ ECHR on account of a domestic court's unexplained rejection of a request to refer a matter to the Luxembourg Court for a preliminary ruling. The Strasbourg Court pointed out that when examining the judgment of the Italian Court of Cassation, the ECtHR found no reference to the applicant's request for a preliminary ruling to be sought or to the reasons the court considered the question raised to not warrant referral to the CJEU: 'It is therefore not clear from the reasoning of the impugned judgment whether that question was considered not to be relevant or to relate to a provision which was clear or had already been interpreted by the CJEU, or whether it was simply ignored." 77 The ECtHR also observed that the reasoning of the Italian Court of Cassation contained no reference to the case law of the CJEU.

Later on, the ECtHR also found violation of Article $6 \S 1$ in another Italian case ${ }^{*} 78$, and it has declared a further case inadmissible because, for one thing, the applicant had exceeded the six-month limit for turning to the Strasbourg Court and, also, that, although the Italian Court of Cassation did not pronounce on the question of referral, it did not have to do so, because, pursuant to its own case law, appeal to the Court of Cassation was not an effective remedy in this case. ${ }^{*}{ }^{7}$ Nevertheless, the ECtHR deemed it necessary to underline that it would have been preferable if the Court of Cassation had explicitly pointed out the rejection of the request for referral.

\section{Appreciating the division of competencies}

In Laurus Invest Hungary KFT and Others, the Strasbourg Court noted that the national court had referred questions to the Luxembourg Court and simply stated that it is for the national courts to examine the impugned measures also from the perspective of the Charter of Fundamental Rights. ${ }^{*} 80$ The Strasbourg Court explained in rather great detail the functioning of the preliminary ruling and refrained from deciding the case itself, as that was premature while it was still pending before the CJEU and national court. The ECtHR stated that the method of scrutiny by the CJEU bears close resemblance to that applied by the ECtHR and that the assessment required by the CJEU explicitly relies, at least partly, on the case law of the ECtHR.

\section{ECtHR case law related to the duty of reasoning for non-referral to the CJEU in a nutshell}

In a nutshell, the ECtHR has so far decided that the ECHR does not guarantee as such a right for a case to be referred by a domestic judge to the CJEU; it has examined the cases pertaining to preliminary references from the standpoint of procedural equity and fair trial and whether the answer to a referral request has been sufficiently clear and precise; and it has restrained itself, however, from going into the substantial motivation of the refusal to refer and thus renounced interpreting EU law. This is in itself positive: the ECtHR shows respect for the division of competencies between the European courts, as well as expressing esteem while communicating with the national courts. The case law analysed stresses the complementary role of the ECtHR in respect of issues of preliminary references and demonstrates the ECtHR's willingness to support the dialogue between national courts and the CJEU. Another sign of good will and a spirit of co-operation is that the ECtHR has invited the European Commission to intervene in such cases as a third party. ${ }^{*} 81$

76 Dhahbi v. Italy, No. 17120/09, 8.4.2014.

77 Dhahbi v. Italy, No. 17120/09, 8.4.2014, para. 33.

78 Schipani v. Italy, No. 38369/09, 21.7.2015.

79 Wind Telecomunicazioni S.P.A. v. Italy (dec.), No. 5159/14, 1.10.2015.

80 Laurus Invest Hungary KFT and Continental Holding Corporation v. Hungary and 5 other applications (dec.), No. 23265/13, 8.9.2015.

81 This is done in accordance with Article 36 §2 of the ECHR and Rule 44 of the Rules of Court. For example, it did so in the Baydar $v$. the Netherlands case; however, in the latter case the European Commission in its reply informed the Strasbourg Court that it did not intend to submit written observations (Baydar v. the Netherlands, No. 55385/14, 28.4.2018, para. 6). 


\section{Scope of the final court's obligation to give its reasons for refusing a request for a preliminary ruling from the CJEU as seen in the ECtHR's judgment in Baydar v. the Netherlands}

The case of Baydar $v$. the Netherlands ${ }^{*} 82$ involved an accelerated procedure for the disposal of appeals in cassation in the interests of efficiency that enabled the Supreme Court of the Netherlands (Hoge Raad) to reject an appeal and declare it inadmissible as having no prospect of success if it does not constitute grounds to overturn the judgment appealed against and does not give rise to the need for a determination of legal issues. The applicant in Baydar lodged a cassation appeal with the Supreme Court, contesting his conviction for, among other things, human trafficking. Not in his appeal itself but rather in his reply to the observations of the Advocate General (advocaat-generaal) of the Supreme Court on his grounds for appeal, he requested the Supreme Court to seek a preliminary ruling from the CJEU on the interpretation of a matter of EU law. The Supreme Court rejected the applicant's appeal (with the exception of the grounds related to the length of the proceedings). Referring to Section 81 (1) of the Judiciary (Organisation) Act, the Supreme Court stated that its decision required no further reasoning 'as the grievances do not give rise to the need for a determination of legal issues in the interest of legal uniformity or legal development'. The applicant complained in the proceedings before the ECtHR that the unexplained refusal of his request for a preliminary ruling breached Article $6 \S 1$ ECHR. The Strasbourg Court found that there had been no violation of Article 6 §1 ECHR.

The ECtHR addressed, for the first time at length, the interaction between its case law on the scope of the requirement to give reasons for a refusal to refer a question to the CJEU for a preliminary ruling and the acceptance that a superior court may dismiss an application for appeal on the basis of summary reasoning. The ECtHR reminded, relying on Dhahbi $v$. Italy, that Article $6 \S 1$ ECHR requires the domestic courts to give reasons, in light of the applicable law, for any decision including refusal to refer a question for a preliminary ruling. This is even more pertinent for the national courts against whose decisions there is no judicial remedy (Article 267 (3) TFEU). They must indicate why they have found that the question is irrelevant, that the EU law provision in question has already been interpreted by the CJEU, or that the correct application of EU law is so obvious as to leave no scope for any reasonable doubt. The Strasbourg Court added that the CJEU itself has ruled that the final domestic courts are not obliged to refer a question regarding the interpretation of EU law if the question is not relevant and if the answer to that question could not have any effect on the outcome of the case. The ECtHR has to verify whether the reasoning for not referring has been handled thoroughly. However, it is not for the ECtHR to examine any errors that might have been committed by the domestic courts in interpreting or applying the relevant law.

Regarding the dismissal of an appeal by a superior court using summary reasoning, the ECtHR recalled its case law and reiterated that the courts of cassation comply with their obligation to provide sufficient reasoning when they take as their basis a specific legal provision, without further reasoning, in dismissing cassation appeals that do not have any prospects of success. The ECtHR confirmed that this line of case law also applied in situations involving national courts against whose decisions there is no judicial remedy under national law (such as the Supreme Court in the instant case).

Finally, the ECtHR took into account the Supreme Court's explanation that it is inherent to a judgment in which the appeal in cassation is declared inadmissible or dismissed by application of and with reference to Section 80 o or 81 of the Judiciary (Organisation) Act that there is no need to seek a preliminary ruling since the matter did not raise a legal issue that needed to be determined. The Strasbourg Court accepted that the summary reasoning contained in such a judgment implies an acknowledgement that a referral to the CJEU could not lead to a different outcome in the case. The ECtHR concluded that no issue of principle arises under Article $6 \S 1$ ECHR when an appeal in cassation that includes a request for referral is declared inadmissible or dismissed with summary reasoning where it is clear from the circumstances of the case - as in the instant case - that the decision is neither arbitrary nor otherwise manifestly unreasonable. One can, however, debate whether the ECtHR was entirely in line with the requirements set in Dhahbi v. Italy.

82 Baydar $v$. the Netherlands, No. 55385/14, 28.4.2018. 


\section{Deductions to be drawn from the Baydar judgment}

This compromise between, on the one hand, the obligation to give reasons and, on the other hand, rejecting an appeal with summary reasoning in the interests of efficiency seems reasonable. The Strasbourg Court has not jeopardised its strict rules about the need for judicial reasoning, nor has it made the practice of summary judgments void. Rather, it has set certain conditions wherein it is acceptable to omit a through presentation of reasoning by taking into account the domestic legislation and practice. Also important is that the ECtHR reiterated the case law of the CJEU confirming that the final domestic courts are not obliged to refer a question of the interpretation of EU law raised before them if the question is not relevant - that is to say, if the answer to that question, whatever it may be, could not have any effect on the outcome of the case. ${ }^{*} 8$ This has to be decided and reasoned by the respective domestic court.

Since there are further cases pending before the Strasbourg Court that pertain to refusal of supreme and even constitutional courts to refer a case to the CJEU for a preliminary ruling, ${ }^{*} 84$ it remains to be seen whether the Baydar case law will be further developed and whether the Strasbourg Court can manage to maintain balance between the obligation to give reasons for a referral and acceptance that superior courts can dismiss an application on the basis of laconic reasoning.

It is to be added that the situation might become more nuanced once Protocol No. 16 of the ECHR is made of effective use and the national courts can refer also questions of interpretation to the Strasbourg Court, although there is no obligation for the superior courts to make use of this possibility.

\subsection{The ECtHR itself and reasoning: Good or bad example now and in the future?}

In the context of importance for judicial reasoning, one could ask how the ECtHR can require the Member States to provide reasons while at the same time not living up to the same standards. ${ }^{*} 85$

This question may arise also as to some other aspects of the rights (to a fair trial) guaranteed by Article 6 ECHR. An example is the duty to render justice within reasonable time: the Strasbourg Court regularly request that domestic courts honour this requirement, whereas it is not rare for proceedings in front of the Strasbourg Court not to meet the standard of reasonable time set by the same court for other jurisdictions.

It has been suggested that the ECtHR, the most visible human rights actor in Europe, should be a champion of procedural justice in its own proceedings and judgments and deliver procedural justice in order to improve applicants' satisfaction and self-worth and to gain compliance and strengthen the legitimacy of the ECtHR, which is inextricably linked to the legitimacy of human rights in Europe. ${ }^{* 86}$

As demonstrated above, scholars have argued that a court's authority 'ultimately rests on giving persuasive legal reasons in support of [...] [its] holdings' ${ }^{*}{ }^{87}$ The same should indeed apply to the CJEU as well as to the ECtHR.

Equally, as seen above, the ECHR imposes a general obligation on the Strasbourg Court to give reasons for its judgments, as well as decisions. Yet there are some important judicial steps that the Strasbourg Court takes that are not reasoned. Practitioners and academics alike have criticised this practice. Within scholarly circles in addressing the level of international human rights protection, as well as at intergovernmental conferences, it has been voiced that the practice of the ECtHR not to reason the decisions of the Grand Chamber panel and the limited reasoning for dismissing an application by the single judge can be seen as problematic. ${ }^{*} 88$

83 Lucio Cesare Aquino v. Belgische Staat, C-3/16, ECLI:EU:C:2017:209, 15.3.2017.

84 Examples: Repcevirág Szövetkezet v. Hungary, No. 70750/14, application communicated to the Hungarian Government on 1.9.2015; Harisch v. Germany, No. 50053/16, application communicated to the German Government on 6.2.2017.

85 See Helena De Vylder. Stensholt $v$. Norway: Why single judge decisions undermine the Court's legitimacy. - Strasbourg Observers blog, 28.5.2014. Available at https://strasbourgobservers.com/2014/05/28/stensholt-v-norway-whysingle-judge-decisions-undermine-the-courts-legitimacy-2/ (most recently accessed on 7.5.2018).

86 Eva Brems, Laurens Lavrysen. Procedural justice in human rights adjudication: The European Court of Human Rights. Human Rights Quarterly 35 (2013) / 1 (February), pp. 176-200. - DOI: https://doi.org/10.1353/hrq.2013.0000.

87 Vlad Perju. Reason and authority in the European Court of Justice. - Virginia Journal of International Law 49 (2009) / 2 , pp. 308-377 (Boston College Law School Legal Studies Research Paper No. 170), on p. 322. Available also from SSRN, via https://ssrn.com/abstract=1324333 (most recently accessed on 5.5.2018).

88 For example, in the Izmir Declaration, about the future of the ECtHR. Under point 2 (e) of the section entitled 'The Court', states expressed the wish to have 'decisions of the panels of five judges to reject requests for referral of cases to the Grand 
Even though there are currently over 55,000 applications pending in front of the Strasbourg Court ${ }^{*} 89$, an individual's rights should not be jeopardised for the sake of efficiency.

In this respect, the dissenting judges in the case Burmych and Others $v$. Ukraine draw attention to the following: "We agree that the Court is called upon to find appropriate judicial ways to ease the backlog problem that is causing serious delays in providing remedy to individual human rights violations. However, the Convention grants individuals the right of access to this Court (Article 34), which means that a properly submitted application must be the subject of a judicial decision. ${ }^{*} 90$

As to the practice of the panel of the Grand Chamber of not giving reasons for its decisions to accept or reject requests that cases be referred to the Grand Chamber, this practice is based on Article 45 ECHR, with provisions added by Protocol No. 11 to the ECHR, by which giving reasons is required only for judgments and for decisions declaring applications admissible or inadmissible. Paragraph 105 of the explanatory report on Protocol No. 11 states that Article 45 ECHR 'does not concern decisions taken by the panel of five judges of the Grand Chamber in accordance with Article 43’. It should also be noted that Rule 73 §2, in fine, of the Rules of Court states that '[r]easons need not be given for a refusal of the request [for referral]'. Since its creation with the entry into force, in November 1998, of Protocol No. 11 to the ECHR, the panel has examined thousands of referral requests and has therefore developed a series of guiding principles that have come to be accepted by it over the years. ${ }^{*}{ }^{11}$ Nevertheless, for some time now, the composition of the five-judge panel for each decision that has been made regarding requests for referral is made public.

The Court has created more efficiency thanks to the filtering capacity of the single judges, which was introduced in 2010 through Protocol No. 14 to the ECHR. Over the years, around $75-90 \%$ of pending applications have been decided by single judges, but this number has diminished lately in favour of other formations as the single-judge filtering mechanism has offered a very efficient 'one in, one out' system of processing of incoming applications. This should not, however, in its own right justify lack of reasoning in individual decisions. From the introduction of the single-judge procedure, the ECtHR had been applying an increasingly summary procedure to deal with the large backlog of tens of thousands of cases. Applicants have received a decision letter rejecting complaints in a global manner. Unmotivated decisions can, however, easily create a feeling of arbitrariness even when there is no arbitrariness behind it. People whose applications are rejected by single-judge decisions expect clarity and reasoning. Therefore, after having eliminated the backlog, the ECtHR adopted, as of June 2017, a new procedure that allows more detailed reasoning to be given in single-judge decisions. This was done also in order to respond to the suggestion made in 2015 by the State Parties at the High Level Conference in Brussels on the ECHR, which welcomed the ECtHR's intention to provide brief reasons for the inadmissibility decisions of a single judge and invited it to do so as of January 2016. ${ }^{*} 92$ Instead of a decision letter, applicants now receive a decision of the Strasbourg Court sitting in single-judge formation in one of the Court's official languages and signed by a single judge, accompanied by a letter in the relevant national language. The decision includes, in many cases, reference to specific grounds for inadmissibility. However, the ECtHR continues to issue global rejections in some cases - for example, where applications contain numerous ill-founded, misconceived, or vexatious complaints. Although this still may not satisfy everyone, it is an important step forward. The Strasbourg Court has admitted that it needs to 'strike a balance between addressing a legitimate concern about the lack of individualized reasoning and maintaining an efficient process for handling inadmissible cases so as not to divert too many resources from examining potentially well-founded cases'. ${ }^{9} 93$

Chamber [...] clearly reasoned', as they considered such a development to contribute to 'avoiding repetitive [referral] requests and ensuring better understanding of Chamber judgments'.

89 From statistics for pending applications as of 31.5.2018, available on the Web site of the ECtHR, at https://www.echr.coe. int/Documents/Stats_pending_month_2018_BIL.pdf (most recently accessed on 29.6.2018).

90 Joint dissenting opinion of judges Yudkivska, Sajó, Bianku, Karakas, De Gaetano, Laffranque, and Motoc. Burmych and Others $v$. Ukraine [GC], No. 46852/13 et al., 12.10.2017, para. 8.

91 For further details, see the following Note of the Strasbourg Court: The general practice followed by the Panel of the Grand Chamber when deciding on requests for referral in accordance with Article 43 of the Convention, 2011. Available on the Web site of the ECtHR at https://www.echr.coe.int/Documents/Note_GC_ENG.pdf (most recently accessed on 7.5.2018).

92 High-level conference on the 'implementation of the European Convention on Human Rights, our shared responsibility'. Brussels Declaration, 27 March 2015, Action Plan: A. Interpretation and application of the Convention by the Court, $1 \mathrm{c}$ ). Available at https://www.echr.coe.int/Documents/Brussels_Declaration_ENG.pdf (most recently accessed on 7.5.2018).

93 Press release of the Strasbourg Court: Launch of new system for single judge decisions with more detailed reasoning, ECHR 180 (2017), 1.6.2017. Available at https://www.penalecontemporaneo.it/upload/CeduENG010617.pdf (most recently accessed on 7.5.2018). 
With Protocol No. 16 ECHR, which enables superior national jurisdictions to seek from the ECtHR an advisory opinion on the interpretation of the ECHR, entering full application soon, the Strasbourg Court has adopted new rules to supplement its Rules. According to Rule 874, para. 2, if the Grand Chamber, while considering the requests for advisory opinion, decides that a request is not within its competence, it shall so declare in a reasoned decision.

\title{
3. Lessons to learn for the Estonian legal system 3.1. Reasoning versus leave to appeal in the Supreme Court of Estonia
}

\author{
A constitutional right to a reasoned judgment?
}

According to $\$ 15$ of the Estonian Constitution ${ }^{*} 94$, everyone whose rights and freedoms have been violated has the right of recourse to the courts. Everyone is entitled to petition the court that hears his or her case to declare unconstitutional any law, other legislative instrument, administrative decision, or measure that is relevant in the case.

It is no secret that the ECHR has been a source of inspiration and a useful example for the "Fundamental Rights' chapter of the Estonian Constitution. ${ }^{*}{ }^{95}$ Therefore, also the commentary to $\$ 15$ of the Constitution applies the ECtHR case law and stresses that the reasoning of a judgment is determined through the nature and circumstances of the case. ${ }^{*}{ }^{6}$ According to Estonian constitutional doctrine, which speaks of a right to reasoned judgment, the judicial reasoning depends upon what the parties have stated during the proceedings, whether the court is the first-instance one or a jurisdiction of higher instance, and how detailed are the applicable norms. ${ }^{*} 97$

The reasoning of a judgment is important for guaranteeing the right to appeal, maintaining judicial peace, convincing parties who have no understanding of legal issues, and guaranteeing the unity and continuity of judicial decision-making.

\section{The duty to give reasons as reflected in Estonian codes of procedure}

The need to present reasoning and the components that make up the reasoning for a judgment are often listed in procedural codes. According to $\$ 157$ of the Code of Administrative Court Procedure ${ }^{*} 98$, a judgment must be in conformity with the law and state its reasons. A judgment is composed of an introduction, an operative part, explanations, a descriptive part, and reasons. Reasons for the judgment must state facts, the evidentiary items that the court relies on in declaring those facts proved, reasons for which the court considers certain evidence to be unreliable or irrelevant, reasons the court has declared some facts generally known, why the court does not agree with the assertions of the participants in the proceedings, the law applied by the court, and conclusions of the court. ${ }^{*} 99$ If the application is dismissed and the reasons have already been provided in the contested administrative act or the decision made upon challenge in respect of this act and the court follows those reasons, the court does not need to repeat the reasons in its judgment and may state that it agrees with said reasons. Rulings are in principle subject to the provisions regarding judgments. ${ }^{{ }^{*} 100}$ If the circuit court annuls the judgment of an administrative court and does not return the matter, it must state its opinion on each submission. ${ }^{* 101}$ If the circuit court adopts an opinion that differs from that of the administrative court, it must state its reasons. If the circuit court upholds the judgment of

94 Adopted by referendum on 28.6.1992, RT 1992, 26, 349, with entry into force on 3.7.1992.

95 For discussion in detail, see Julia Laffranque. Euroopa Inimõiguste Kohus ja Eesti õigus ['The European Court of Human Rights and Estonian Law']. Tallinn: Juura 2017, p. 17.

96 Madis Ernits et al. (eds). Eesti Vabariigi Põhiseadus, Kommenteeritud väljaanne ['The Constitution of the Republic of Estonia: A Commentary’], Chapter II, §15. Tallinn: Juura 2017, para. 34.

97 Ibid., para. 34.

98 Code of Administrative Court Procedure, adopted 27.1.2011, RT I, 23.2.2011, entry into force 1.1.2012.

99 Ibid., para. 165.

100 Subsection 178 (3) of the Code of Administrative Court Procedure.

101 About the circuit court judgment, see §201 Code of Administrative Court Procedure. 
the administrative court without divergence from it, the circuit court is not required to state reasons for its judgment. In such a case, the circuit court must state that it agrees with the reasons given by the administrative court. The circuit court may also add the reasoning, if necessary. The circuit court may also enter a judgment in simplified proceedings.

Similarly, the Code of Criminal Procedure ${ }^{{ }^{102}}$ states specific requirements for reasoning, with regard to conclusions of a judgment of conviction and of acquittal, and it also speaks about reasoned orders and procedural decisions of a court in criminal matters. ${ }^{*}{ }^{103}$ Likewise, the Code of Misdemeanour Procedure ${ }^{*} 104$ sets requirements for a reasoned ruling, on issues to be adjudicated upon in making of a court judgment, and on contents of court judgments, also addressing the circuit court judgment.

In the Code of Civil Procedure ${ }^{* 105}$, dealing with civil court procedure, the requirements for a judicial decision are set by $\S \S 434-444$. The code also regulates some exceptions: when the court can omit reasoning from its judgment during the simplified proceedings.

All codes of procedure include a description of the structure of the judgment of the supreme court (which in Estonia is at the same time supreme administrative court, constitutional court, and court of cassation for civil and criminal matters). ${ }^{*} 106$ The Code of Criminal Procedure, as well as the Code of Misdemeanour Procedure, sets particular requirements for the introduction and also reasoning of the Supreme Court judgment. ${ }^{* 107}$ In general, the same rules applied for the county court / respective administrative court (court of first instance) judgment are pertinent, with some additional information in the introductory part of the judgment (e.g., naming the person who has lodged the appeal in cassation). If the Supreme Court changes the judgment of lower courts, integral text for the operative part has to be produced. The descriptive part is followed by reasons, which need to include conclusions and laws that the Supreme Court has applied, as well as the issues that the Supreme Court finds were wrongly addressed by the lower courts. In the case of the Supreme Court annulling the judgment of a lower court, the Supreme Court must state its position on all assertions, objections, and points of procedure in relation to which the circuit court would have to express its position. If the Supreme Court does not alter the judgment of a lower court and concurs with it, it does not have to restate the reasoning of the lower court and does not need to state the reasons for its own judgment. In such a case, the Supreme Court must state that it agrees with the reasons given in the judgment of the circuit court. If necessary, it may, however, add its own motives. Where a valid reason for this exists, particularly in simplified proceedings, the Supreme Court may, when it dismisses the appeal in cassation, enter a judgment that consists solely of the operative part. The Supreme Court does not establish facts.

The Constitutional Review Court Procedure Act, which provides for the competence of the Supreme Court as the court of constitutional review, states that a judgment shall be reasoned. ${ }^{{ }^{*} 108}$ The Supreme Court can also give opinions, which also must be reasoned. ${ }^{*}{ }^{109}$

Judgments of the Supreme Court enter into force as of the date they are made public and are not subject to appeal.

\section{The Supreme Court's interpretation of the scope of lower courts' duty to give reasons}

The Supreme Court of Estonia has in its turn interpreted the obligation to give reasons as an obligation of a court to give in the reasoning part of the judgment clear and exhaustive explanations about the operative part. ${ }^{*} 10$ These explanations need to be non-contradictory ${ }^{*}{ }^{* 11}$ and convincing so that the reader can follow the proceeding of judicial reasoning based on the inner belief of a judge. The judgment should reveal how and on the basis of which evidence the court came to its conclusions (this applies to both civil and criminal

102 Code of Criminal Procedure, adopted 12.2.2003, RT I 2003, 27, 166, entry into force 1.7.2004.

103 Code of Criminal Procedure $\S 305^{1}$ and $\S \S 306,311-314,342$.

104 Code of Misdemeanour Procedure, passed 22.5.2002, RT I 2002, 50, 313, entry into force 1.9.2002. See, in particular, $\S \S 48,108-112,153$.

105 Code of Civil Procedure, adopted 20.4.2005, RT I 2005, 26, 197, entry into force 1.1.2006.

106 Section 689 of the Code of Civil Procedure; Section 231 of the Code of Administrative Court Procedure.

107 Section 363 of the Code of Criminal Procedure; Section 176 of the Code of Misdemeanour Procedure.

108 Constitutional Review Court Procedure Act, adopted 13.3.2002, RT I 2002, 29, 174, entry into force 1.7.2002, §57 (3).

109 Constitutional Review Court Procedure Act, $§ 591$ (3) (as added in RT I 2005, 68, 524, with entry into force on 23.12.2005).

110 Supreme Court of Estonia judgments in case No. 3-1-1-10-11, 1.7.2011 and case No. 3-3-1-14-15, 27.5.2015.

111 Supreme Court of Estonia. Judgment in case No. 2-15-18582/47, 22.11.2017. 
cases). ${ }^{*} 12$ The operative part and the reasoning must not be mutually contradictory. In criminal cases in a situation of 'word against word', the reasoning must be particularly thorough. ${ }^{* 113}$ The Supreme Court of Estonia has added also that copying the observations of the opposing party as the reasoning for the judgment is not presenting grounds to annul the judgment. Nevertheless, for the sake of an objective and fair trial, one has to avoid such reasoning. When the court agrees with the submissions by a party and uses them as part of its reasoning, it has to say so. ${ }^{*} 14$ Likewise, the Supreme Court does not forbid an administrative court to use the reasoning of the administrative body that first ruled on the dispute. Nevertheless, if the applicant has contested the evidence, the court has to examine the evidence itself and give answer to the new arguments of the parties. ${ }^{*} 15$ This applies also to the arguments that have already been used in administrative proceedings but have not been answered by the administrative body. The court needs to explain why it does not agree with the party's submissions.

As to the court of appeal, the Supreme Court has stated that the appellate court has to explain the arguments in its judgment that differ from the first-instance court judgment. ${ }^{*} 16$ Furthermore, the appellate court has to explain why it does not accept the evidence provided by the parties ${ }^{*} 117$ and state the evidence on which it has based its reasoning. ${ }^{*} 118$

However, in addressing civil matters the Supreme Court has said that an operative part of a judgment has to be understandable and enforceable even without the rest of the text of the judgment. ${ }^{* 119}$

The Supreme Court has stressed that the legal arguments of the reasoning of a court should not be a surprise to the parties and has to be reasonably foreseeable by them. ${ }^{*}{ }^{120}$ The Supreme Court has also emphasised that if a circuit court decides on the basis of the same evidence to make a judgment completely opposite the first-instance court's, it has to apply higher standards of reasoning. ${ }^{*} 21$ This has also been reflected in the ECtHR case law concerning Estonia. ${ }^{* 122}$ There are a few other cases that have been decided by the Strasbourg Court too that are related directly or indirectly to the obligation of Estonian courts to give reasons.

\section{The duty of Estonian courts to give reasons as seen by the Strasbourg Court}

The ECtHR has criticised an Estonian county court for not giving sufficient reasons for its decision to use simplified proceedings and not hear the applicant. ${ }^{*} 123$ The Strasbourg Court, while accepting the need for simplified proceedings in certain circumstances and cases, emphasised, however, that the obligation under Article $6 \S 1 \mathrm{ECHR}$ for the domestic courts to give reasons applied not only for judgments but also for major procedural decisions issued in the course of the proceedings. In another case, the ECtHR found a violation of Article 6 ECHR for, among other reasons, the circuit court having not been able to correct the reasoninglacking first-instance court judgment. ${ }^{{ }^{1} 124}$ Considering the adjudication about legal fees in a plea-bargain settlement procedure, the ECtHR was not satisfied with the Estonian court having made no decision on the applicants' claim for legal costs; therefore, Article 6 ECHR was deemed breached. ${ }^{*} 25$

\footnotetext{
112 Supreme Court of Estonia. Judgment in case No. 2-10-4395/107, 13.11.2017; Supreme Court of Estonia. Judgment in case No. 3-1-1-75-14, 26.11.2014.

113 Supreme Court of Estonia. Judgment in case No. 3-1-1-26-13, 20.3.2013.

114 Supreme Court of Estonia. Judgment in case No. 3-3-1-76-24, 17.3.2015.

115 Supreme Court of Estonia. Judgment in case No. 3-3-1-27-14, 2.6.2014.

116 Supreme Court of Estonia. Judgment in case No. 3-3-1-71-14, 12.3.2015.

117 Supreme Court of Estonia. Judgment in case No. 3-3-1-12-98, 10.4.1998; Supreme Court of Estonia. Judgment in case No. III-3/1-3/95, 17.2.1995.

118 Supreme Court of Estonia. Judgment in case No. 3-3-1-4-99, 19.2.1999.

119 Supreme Court of Estonia. Judgment in case No. 2-15-12837/48, 25.10.2017.

120 Supreme Court of Estonia judgment in case No. 3-3-1-58-13, 8.11.2013 and in case No. 3-3-1-25-14, 12.6.2014.

121 Supreme Court of Estonia judgment in case No. 3-1-1-14-14, 30.6.2014.

122 Kashlev v. Estonia, No. 22574/08, 26.4.2016.

123 Pönka v. Estonia, No. 64160/11, 8.11.2016.

124 Rummi v. Estonia, No. 63362/09, 15.1.2015.

125 Leuska and Others $v$. Estonia, No. 6473/11, 7.11.2017.
} 


\section{The mechanism of leave to appeal in the Estonian Supreme Court}

As far as access to the Supreme Court is concerned, then in civil, criminal, and administrative cases there exists a leave-to-appeal system in a sense. ${ }^{{ }^{1} 126}$ It is not classical leave to appeal in stricto sensu, in which a court has to give prior permission before a legal remedy can be used. The freedom of parties to lodge cassation appeals remains untouched. However, the Supreme Court can refuse to open proceedings on appeal. This leave-to-appeal system does not exist for constitutional review matters, which are anyway mostly initiated by the regular courts, as there is no individual constitutionality claim possible except in exceptional circumstances wherein no other remedy exists to protect the fundamental rights at issue. According to the Courts Act, acceptance of matters that fall within the jurisdiction of the Supreme Court for proceedings shall be decided on by a panel of at least three members of the Supreme Court on the basis provided for by law regulating judicial procedure. ${ }^{*} 127 \mathrm{~A}$ matter is accepted for proceedings if the hearing thereof is demanded by at least one justice of the Supreme Court. This leave to appeal is also called opening of proceedings on an appeal in cassation or acceptance/refusal of an appeal in cassation by a ruling. It is in a nutshell characterised by the various codes of procedure as follows ${ }^{* 128}$ : the Supreme Court, acting as a panel of three members, decides, without summoning the participants of the proceedings. The Supreme Court opens proceedings on an appeal in cassation if (at least one justice of) the Supreme Court ${ }^{* 129}$ thinks that 1 ) the positions stated in the appeal warrant the conclusion that the circuit court has incorrectly applied a rule of substantive law or has significantly infringed the rules of court procedure, which has resulted or could have resulted in an incorrect judgment being entered, and, 2) regardless of the first condition, if a decision on the appeal is of considerable importance from the point of view of ensuring legal certainty or elaboration and uniformity of the approach in the case law of the courts. The leave to appeal in cassation is refused if the Supreme Court is convinced that none of the above-mentioned grounds exists for the opening of proceedings on the appeal. The Code of Civil Procedure lists the grounds for determining that the circuit court has significantly infringed the rules of procedure. ${ }^{*} 30$ In civil cases, the Supreme Court need not accept an appeal in cassation filed in a matter of a proprietary claim if the appellant in cassation contests the judgment of the circuit court to an extent less than ten times the minimum monthly wage established by the Government of the Republic. In administrative cases, proceedings are not required to be opened on the appeal also in the event that the Supreme Court is convinced that it will be impossible to achieve the aim of the appeal by conducting the proceedings. As of rather recently, a new condition has been added - namely, if the impingement on the

126 The possibility to decide whether to adjudicate a case exists in Estonian law under certain rules also for the courts of lower instance - for example, as far as the examination of whether the application has prospects of succeeding or whether the objective sought by the plaintiff could not be achieved by the action is concerned. See $\S \S 371$ (2) and 423 (2) of the Code of Civil Procedure. For detailed discussion, see the following two analyses of legal practice of Estonian courts carried out by the Supreme Court research department: Margit Vutt. Hagi menetlusse võtmisest keeldumine või läbi vaatamata jätmine õigusliku perspektiivituse tõttu, Kohtupraktika analüüs ['Refusing to accept an action or not taking cognisance of an action since it lacks a legal perspective: Case law analysis']. Tartu: Riigikohus 2012; for administrative law, Liina Kangur. Kaebuse ilmselge põhjendamatus ['Clear unfoundedness of an appeal']. Tartu: Riigikohus. These issues will not be examined in the current paper, as these decisions, under the law, including case law, mostly an elevated requirement of particularly solid reasoning, are mostly appealable, are not related to the duty of the final court to refer an EU law interpretation question to the CJEU, and would most likely not involve the issues of validity of EU law either (when all courts have the duty to refer).

127 Courts Act, adopted 19.6.2002, RT I 2002, 64, 390, entry into force 29.7.2002, §26 (2).

128 Code of Civil Procedure, adopted 20.4.2005, RT I 2005, 26, 197, entry into force 1.1.2006. Section 679 of the Code of Civil Procedure; Section 219 of the Code of Administrative Court Procedure; Section 349 of the Code of Criminal Procedure; Section 160 of the Code of Misdemeanour Procedure.

129 This requirement is expressis verbis added to $\$ 349$ of the Code of Criminal Procedure and is also stipulated in general terms in $\S 26$ of the Courts Act and in detail in the Rules of the Supreme Court - Riigikohtu kodukord, from 21.2.2006, as amended in 2008, 2009, and 2012, RT III, 19.6.2012, 4.

130 Section 669 of the Code of Civil Procedure states:

A circuit court has materially violated a provision of procedural law in making a judgment, if at least one of the following circumstances become evident:

1) the principle of legal hearing or the public nature of proceedings has been violated;

2) the court judgment concerns a person who was not summoned to court pursuant to law;

3) the matter was adjudicated by an unlawful court panel, including a court panel containing a judge who should have removed himself or herself;

4) a party was not represented in the proceeding pursuant to law and the party had not approved such representation in the proceeding;

5) the judgement is not reasoned to a significant extent.

The Supreme Court may also deem a violation not specified in Subsection (1) of this Section to be a material violation of a provision of procedural law if the violation could affect the result of adjudication of the matter in the circuit court. 
right that the appeal is intended to protect is a minor one and the law would permit the matter to be heard by way of simplified proceedings, the Supreme Court opens proceedings on the appeal only if the decision of the Supreme Court holds fundamental importance from the point of view of uniform application of the law or of development of law. ${ }^{*}{ }^{1} 1$ If an appeal in cassation is clearly justified or clearly unjustified, the decision on acceptance of the appeal in cassation or rejection of the appeal may be made without sending the appeal in cassation to the other persons. The opening of proceedings on an appeal in cassation, or refusal to open such proceedings, is formalised as a ruling of the Supreme Court. The ruling to give or refuse leave to appeal sets out the legal basis for the granting or refusal of leave to appeal. This usually consists of one sentence with reference to a relevant article of a respective procedural code. The following is an example: 'On the basis of \$344 (5) of the Code of Criminal Procedure, not opening proceedings on appeal in cassation of X.Y.' No further reasoning is present. A copy of the ruling is sent to all participants in the proceedings either by the Supreme Court or, since 1.9.2011 in criminal cases wherein the file is sent back to the county court, by the county court. The ruling is final. In cases of refusal, the file is returned to the relevant court. The outcome is published on the website of the Supreme Court without delay.

\section{Polemics and numbers surrounding the leave-to-appeal system}

I will not elaborate on the reasons for which the leave-to-appeal system was created historically for the Supreme Court. It goes without saying that one of the aims was (and is) to optimise the work of the Supreme Court and to concentrate on important cases and, if need be, on remedying serious errors of other courts. In general, the leave-to-appeal system at the Supreme Court level has now become more or less accepted by the parties and legal community in Estonia, although some concerns have been voiced now and then as to the possible arbitrariness of such a mechanism. ${ }^{*} 3^{2}$ It has to be noted that initially the three-member panel that decided on the leave to appeal was composed of one member each of three different chambers (civil, criminal, and administrative) of the Supreme Court, with a six-month rotating basis. Nowadays the panel is composed of three judges within a single chamber for at least three months, while the president of the Supreme Court and a member of another chamber to be appointed by the president of the Supreme Court can have the right to participate in deciding on the leave to appeal. The law clerks and assistants also are involved in the process. ${ }^{*} 33$ In 2017, during the Court en banc sitting, ${ }^{*} 134$ one judge questioned the transparency of this system in comparison with the old leave-to-appeal panel, with the three-member panel composed of members of different chambers, and asked whether the system creates frustration among the applicants. The president of the administrative law chamber of the Supreme Court answered that a threelevel court system does not mean that all cases have to be decided in three levels, that even nowadays the judges from other chambers of the Supreme Court can be involved in decision-making, although this is rare at the leave-to-appeal stage and more frequent at the decision-making stage. He added that for the general public it does not matter much whether the leave to appeal is decided upon within the chamber or by a panel with members from different chambers; what matters is that the litigants would like to see reasons for refusal of leave to appeal. The president of the administrative law chamber revealed that in fact the judges do write down reasons, but only for themselves, which can be used in order to remember why in one

131 See Amendments to the Code of Administrative Court Procedure, RT I, 28.11.2017, 1 - entry into force 1.1.2018.

132 See, for example, Peeter Ploompuu. Kas riigikohus kuritarvitab suvaõigust? ['Is the Supreme Court abusing its discretion?']. Eesti Päevaleht, 30.11.1999, about the leave to appeal in ownership reform cases involving unlawfully expropriated property. About leave to appeal and reasoning, see also Virgo Saarmets. Individuaalne konstitutsiooniline kaebus põhiseaduslikkuse järelevalve kohtus ['Individual constitutional actions before the constitutional review court']. - Juridica 2001/6, pp. 376-392, among others, with regard to plans to reform constitutional review and create a separate constitutional court with a leaveto-appeal system whereas the decisions to give or to refuse leave to appeal should be explained; Jaak Kirikal. Mitu kõrgemat kohut on Riigikohtus? ['How many supreme courts does the Supreme Court include?']. - Juridica 1998/10, pp. 527-531, about the legitimacy of the panel that used to decide on leave to appeal before it was handed over to each chamber of the Supreme Court; Julia Vahing. Euroopa ühenduste kohtu ja Euroopa Liidu liikmesriikide kohtute ning Eesti kui võimaliku liikmesriigi kohtute vaheline koostöö ['Co-operation between the Court of Justice of the European Communities, courts of the Member States of the European Union, and the courts of Estonia as a candidate state']. - Juridica 1998/5, pp. 250-255, about the problematic of no reasoning in a leave-to-appeal system in connection with referrals to the Luxembourg Court.

133 See Rules of the Supreme Court, paras 35-38.

134 The Court en banc comprises all Estonian judges and is convened every year on the second Friday of February. The Court en banc discusses the problems of administration of justice and other issues concerning courts and the work of judges and elects members to the governing, administrative, disciplinary, and training bodies of judges; see $\S 38$ of the Courts Act. 
or another case leave to appeal was not granted. However, when these reasons should also be made public, then the leave-to-appeal system as a filter would lose its sense, and, regrettably, there are at the moment no alternative solutions in sight that are better than the current system. ${ }^{*} 35$

As for statistics, in 2017 the Supreme Court granted leave to appeal in civil cases for 196 out of 993 claims that were examined. The corresponding numbers for the same year are for criminal cases 72 out of 693 and for administrative cases 80 out of 921 . $^{* 136}$

\section{Leave to appeal to the Estonian Supreme Court as seen by the Strasbourg Court's predecessor}

In the case Aadu Oll v. Estonia, ${ }^{*} 137$ the applicant claimed that his right to a fair trial (Article 6 ECHR) was violated because the Supreme Court of Estonia did not give any reasons when rejecting his appeal. The European Commission of Human Rights (the Commission) recalled that the right to appeal in civil cases does not feature among the rights and freedoms guaranteed by the ECHR. No provision of the ECHR requires an appeal to a supreme court; if a state makes provision for such an appeal, it is entitled to prescribe the rules by which this appeal shall be governed and fix the conditions under which it may be brought. The Commission concluded that an examination of whether leave to appeal shall be granted is only an examination addressing whether the conditions in the Code of Civil Procedure are satisfied. It does not amount to an examination of the merits of the appeal. When a supreme court determines, in a preliminary examination of a case, whether or not the conditions required for granting leave to appeal have been fulfilled, it is not making a decision related to 'civil rights and obligations'. The Commission hence found Article 6 ECHR not applicable.

The ECtHR has not come back to this issue; it has considered the refusal of leave to appeal to the Supreme Court to be a final decision of domestic remedy that has to be exhausted before application to the Strasbourg Court. Likewise, the CJEU has in a Swedish case decided that a national court whose decisions can be appealed only if the supreme court declares their appeal admissible is not a court against whose decision there is no judicial remedy. ${ }^{*} 138$

\subsection{Leave to appeal in the Supreme Court of Estonia and preliminary references to the Luxembourg Court}

\section{Practice of Estonian courts asking for preliminary references from the CJEU in general}

According to the official statistics, as of the end of 2017, Estonian courts have since Estonia's accession to the European Union (in 2004) made, in all, 25 references for preliminary rulings; 10 of them have been made by the Supreme Court and 15 by other courts ${ }^{*} 139$, with both first- and second-instance courts having made referrals. ${ }^{*}{ }^{140}$ The first questions for a preliminary ruling by the CJEU were referred by the Supreme Court of Estonia in an administrative law case (on agricultural subsidies) in 2007. ${ }^{*} 141$ The Supreme Court in particular, the administrative chamber of the Supreme Court - had already, as it has continued to do, explained in detail on which occasions an Estonian court should request a reference for a preliminary ruling

135 See Andrus Miilaste, Ivo Pilving in the Minutes of the Court en banc of 9-10.2.2017. Available at https://www.riigikohus. ee/sites/default/files/Kohtunike_XVI_korralise_t\%C3\%A4iskogu_protokoll_10-02-2017.pdf (in Estonian) (most recently accessed on 8.5.2018).

136 Statistics of the Supreme Court for 2017, available on their Web site in the Estonian language at https://www.riigikohus. ee/et/riigikohus/riigikohtu-tegevust-iseloomustav-statistika (most recently accessed on 8.5.2018).

137 Aadu Oll v. Estonia, European Commission of Human Rights, No. 35541/97, 1.7.1998.

138 Lyckeskog, C-99/00, 2002, 4.6.2002.

139 Rapport Annuel. Activité Judiciaire, CJEU, 2017, p. 127.

140 See the updated list of all referrals made by the Estonian courts on the Web site of the Supreme Court of Estonia, available in Estonian at https://www.riigikohus.ee/et/eesti-kohtute-eelotsusetaotlused (most recently accessed on 8.5.2018). In fact, as of May 2018 there have been, all told, 26 referrals, 10 from the Supreme Court and 16 from lower jurisdictions.

141 Ruling of the Supreme Court No. 3-3-1-95-06 (JK Otsa Talu OÜ), 14.5.2007. See also Julia Laffranque. Riigikohtu halduskolleegiumi Euroopa Kohtult eelotsuse küsimise kogemus ['Experience of the Supreme Court in asking for a preliminary ruling']. - Kohtute aastaraamat ['The Courts Yearbook'], 2007, pp. 113-122. 
from the CJEU. ${ }^{*} 142$ The Supreme Court has had a leading role in giving guidance to the other Estonian courts on when and how to ask for preliminary references, as well as explained the acte clair doctrine. On the website of the Supreme Court, one can find all the referrals from Estonian courts and their answers that are available thus far. There also have been useful materials ${ }^{*} 143$ written in Estonia about preliminary references, and continuous training of judges has been helpful in instructing Estonian judges in how to communicate with the Luxembourg Court. The topics of the Estonian references for preliminary rulings have covered mostly agriculture and customs issues. The Supreme Court has itself suggested a possible solution in a referral ${ }^{*}{ }^{144}$, and the Luxembourg Court has reformulated the questions in order to better understand the aim of the referral made by the Tallinn administrative court. ${ }^{*} 145$ Although in many cases, such as that of the first Estonian referral, the courts have themselves ex officio initiated the preliminary rulings procedure, more and more often the representatives of the parties urge the courts to refer questions to the CJEU.

\section{Answering the request of the parties to refer the case to the CJEU in the Estonian Supreme Court as compared to the conditions of the Baydar judgment}

Already in 2006, the Supreme Court (civil law chamber) had to decide whether an application of a party to the court to request that court to ask for a preliminary ruling from the CJEU is an independent procedural request or instead part of a legal position of a party and part of interpretation and application of substantial law. ${ }^{*} 146$ The Supreme Court favoured the latter approach.

Now a situation can occur wherein a lawyer asks the court to refer questions to the Luxembourg Court but the court in its judgment refuses to do so and the Supreme Court, with one laconic sentence, does not give leave to appeal. How will this situation mesh with the requirement of the Strasbourg Court that the refusal to refer be reasoned?

Can one deduce in these cases that the Supreme Court accepts the reasoning for non-referral given by the circuit court and that it is implicit from its well-developed case law addressing leave to appeal, such that no further reasoning is needed? As stressed above, under both EU law and ECtHR case law, the Supreme Court has no duty to refer if the question is irrelevant to the outcome of the case or if other C.I.L.F.I.T. criteria are met. In other words, if the circuit court has explained why it is irrelevant, the refusal of leave to appeal can easily be seen as a confirmation of the circuit court standpoint by the Supreme Court.

However, it gets more complicated if the circuit court has not dealt with the issue at all, if the issue is being raised for the first time on cassation level, as in Baydar, where the applicant came up with the request for referral not even in his appeal before the Supreme Court but rather in his answers about his appeal in response to the advocate-general of the Supreme Court of the Netherlands - although the appeal court had addressed the EU law issues as such but not the specific request to refer to the CJEU. Then again, both the CJEU and the ECtHR have stressed that it is for the national court only and not for the parties to determine whether to refer or not. Can it hence be deduced that even if the appellate court has not examined the request and/or the concrete questions posed by the party in order to ask for a preliminary reference from

142 See for example, the Supreme Court of Estonia judgment in case No. 3-3-1-74-05, 25.4.2006, and, more recently, the Supreme Court of Estonia judgment in case No. 3-15-118/21, 27.9.2017.

143 See Julia Laffranque. Eelotsuse küsimine Euroopa Kohtult ['References to the European Court of Justice']. Tartu: Eesti Õiguskeskus 2005. See also Julia Laffranque. Euroopa Kohtu eelotsus Eesti kohtupraktika mõjutajana ['Influence of the preliminary ruling of the CJEU on Estonian case law']. - Riigikogu Toimetised 2006/14, pp. 83-90; Uno Lõhmus, Liina Teras. Euroopa Kohtust ja eelotsusemenetlusest ['On the CJEU and preliminary references']. - Riigikogu Toimetised 2006/14, p. 82.

144 Ruling of the Supreme Court No. 3-3-1-95-06 (JKOtsa Talu Ö̈), 14.5.2007. However, the CJEU did not follow the suggestion made by the Supreme Court. See JK Otsa Talu, C-241/07, 4.6.2009; see also Lembit Uibo. Euroopa Kohus ja Eesti tegemised ['The European Court and Estonian activities']. - Yearbook of the Ministry of Foreign Affairs, 2010, report available online in Estonian from the Ministry of Foreign Affairs of Estonia, at: http://vm.ee/et/euroopa-kohus-ja-eesti-tegemised (most recently accessed on 9.5.2018).

145 Balbiino, C-560/07, 4.6.2009; see also Tïna Pappel. Käänuline tee minu esimese eelotsuse taotluseni ['The cumbersome road to my first reference for a preliminary ruling']. - Kohtute aastaraamat ['The Courts Yearbook'], 2007, pp. 123-125; Uno Lõhmus. Eesti kohtute esimesed eelotsusetaotlused said lahenduse: Euroopa Kohtu 4. juuni 2009. a otsused asjades C-241/07 (JK Ots Talu) ja C-560/07 (Balbiino) ['The first requests by the Estonian courts for a preliminary ruling have been answered: The judgment of the European Court of Justice in Case C-241/07 (JK Otsa Talu) and C-560/07 (Balbiino)']. Juridica 2009/5, pp. 321-327.

146 Supreme Court of Estonia, judgment in case No. 3-2-1-4-06, RT III, 2006, 12, 118, 30.3.2006. 
the CJEU, the appellate court has taken notice of the EU law aspects and has, although not stating it expressis verbis, obviously not found it necessary to refer? Is it enough to accept there being no further reasoning by the Supreme Court either and understand the Supreme Court's dismissal as agreement with the appellate court? As seen above, the ECtHR has even in that case found no violation of Article 6 §1 ECHR. One has to note that under Estonian law, unlike in the Baydar case, in some obvious cases the Supreme Court does not need to send the appeal in cassation to other parties for their comments.

But what if the circuit/appellate court has not at all dealt with the EU law, not even in substance, let alone talked about formulating questions to the CJEU? Can the applicant be allowed to raise EU law aspects at this late stage, in his or her appeal to cassation, and is the Supreme Court obliged to respond? What if in the meantime there have been developments in the EU law that were not there when the appellate court made its decision?

The Strasbourg Court has in its judgment in the case Baydar $v$. the Netherlands stated that in the context of accelerated procedures within the meaning of Section 80a or 81 of the Judiciary (Organisation) Act of the Netherlands, no issue of principle arises under Article $6 \S 1$ ECHR when an appeal in cassation that includes a request for referral is declared inadmissible or dismissed with summary reasoning where it is clear from the circumstances of the case that the decision is not arbitrary or otherwise manifestly unreasonable. ${ }^{*} 47$ Could this be understood as accepting also a laconic reference to a relevant legal base in the refusal of leave to appeal by the Estonian Supreme Court? Similarly to the Supreme Court of the Netherlands in the Baydar case, the Estonian Supreme Court can dismiss an application for appeal if this does not lead to a need for a determination of legal issues in the interests of legal uniformity and legal development.

Or in these cases, which involve problematics of non-referral to the CJEU, should the Estonian Supreme Court make an exception and either add separate reasoning to the refusal of leave to appeal or grant the leave to appeal and confirm with its own reasoning the non-referral to the CJEU? The first solution would mean unequal treatment between applications, depending upon whether there is any EU law context, particularly demand for a referral to the CJEU, or not; the other applications for which leave to appeal is refused would remain with summary reasoning. It does not make sense to take EU law out of the regular context; EU law should be seen as part of the Estonian legal system. The second option would not be rational from the point of view of procedural economy and would mean loss of time. On the other hand, for the applicant both solutions would definitely provide much clearer solutions to the relevant problems than the current situation does.

However, in another case before the Supreme Court, quite the opposite happened: the lawyer of a party did not want the circuit court to refer a question to the Luxembourg Court and in front of the Supreme Court contested the ruling of the circuit court, which had postponed the case and requested a preliminary ruling from the CJEU. ${ }^{*} 148$ According to the applicant, the circuit court was wrong in asking for a preliminary reference. One reason for the objection could have been the length of the preliminary ruling procedure before the CJEU, which delays the overall time to adjudicate the case. The Supreme Court found that the ruling on suspending the proceedings and asking for a preliminary ruling was contestable under national law. However, in the case at hand it found also that the circuit court had rightly referred a question to the CJEU and even added its own questions to be referred in addition to the list of questions prepared by the circuit court.

In this context, it is to be welcomed that there is real substantial discussion among Estonian judges and litigants about the preliminary reference procedure, and that the Estonian courts consider explanation to the parties with regard to a need to refer the questions to the CJEU to be an obligation, so that referral would be reasonably predictable to the parties and not come as a surprise. ${ }^{*}{ }^{149}$ The parties should have an opportunity to comment on the decision to refer.

Proceeding from the Baydar judgment, one could perhaps suggest and envisage that the Supreme Court of Estonia, if such an occasion prevails, explains exceptionally in one decision of refusal of leave to appeal that involves a case entailing a reference to the CJEU, similarly to that of the Supreme Court of the

147 See Baydar $v$. the Netherlands, No. 55385/14, 28.4.2018, para. 50.

148 Supreme Court of Estonia, judgment in case No. 3-3-1-2-13, 21.3.2013; Liivimaa Lihaveis, C-175/13, 10.2.2015.

149 See Priit Pikamäe. Mõningatest Euroopa Kohtult eelotsuse taotlemise praktilistest aspektidest Eesti kogemuse näitel ['Thoughts on some of the practical aspects of an order for a preliminary ruling by the Court of Justice of the European Union, based on an Estonian example']. Speech at the round-table meeting of the Presidents of the Supreme Judicial Courts of the European Union, Luxembourg, 17.3.2014. Available at https://www.riigikohus.ee/sites/default/files/elfinder/dokumendid/ ettekanne_luxembourg_17_03_eelotsused.pdf (in Estonian) (most recently accessed on 9.5.2018), with further references to the Supreme Court of Estonia, judgment in case No. 3-3-1-56-13, 16.12.2013. 
Netherlands, that the requirements of the codes of procedure with regard to leave to appeal are related also to the EU law issues. The Supreme Court has occasionally explained in decisions refusing leave to appeal as obiter dicta some legal situations, as, for example, with the case that ended up as Leuska v. Estonia in front of the Strasbourg Court. ${ }^{*} 150$ For instance, according to Baydar $v$. the Netherlands, the Supreme Court of the Netherlands in its judgment of 26 May 2015 (ECLI:NL:HR:2015:1332) explained its practice as regards the application of sections $80 a$ and 81 of the Judiciary (Organisation) Act in relation to a request for referral to the CJEU made in that case. ${ }^{* 151}$

As seen above, the Estonian Supreme Court has also considered the question of referral to be a part of issues of law.

The Strasbourg Court took into account the explanation by the Supreme Court of the Netherlands and accepted that the summary reasoning contained in such a judgment implies an acknowledgement that a referral to the CJEU could not lead to a different outcome in the case. ${ }^{*}{ }^{152}$

\section{Conclusions}

As seen from the above, there are very good reasons to give reasons: the duty to give reasons is in the interest of those seeking justice and is of paramount importance both in European law - including the case law of the Strasbourg and Luxembourg courts - and in national law as well, as demonstrated in line with the example of Estonian law, including the case law of the Supreme Court of Estonia. The duty to give judicial reasons is a fundamental/constitutional right that is part of the right to a fair trial.

There should be strong reasons for not giving reasons. Exceptions to the duty to give reasons are rare and strict. However, they are tolerated more on appeal, particularly on cassation level. Contrary to that in criminal cases, the right to appeal in civil cases does not feature among the rights and freedoms guaranteed by the ECHR, and, according to the ECtHR, the states are free to determine their procedural laws pertaining to admission to cassation.

Preliminary rulings are an important tool in protection of the rights of individuals in the EU and in enhancing the dialogue between national courts and the Luxembourg Court. The Strasbourg Court with its case law has supported the adherence of the national courts to the requirement of fulfilling the duty in certain cases or for certain courts to refer a question to the Luxembourg Court. It has duly articulated again the C.I.L.F.I.T. criteria and the case law of the CJEU that has followed. By doing so, the Strasbourg Court has respected the division of competencies between different European and national courts and limited its supervision to the procedural aspects - namely, whether a non-referral has been duly reasoned or not. It has indeed pointed out procedural deficiencies if need be. At the same time the Strasbourg Court has emphasised that there is no right for a case to be referred by a domestic judge to the Luxembourg Court. According to the case law of the Luxembourg Court, it is the national court only and not the parties who decide to bring the matter to the Luxembourg Court. The Strasbourg Court has with talent found a balance between the duty to give reasons and the acceptance of certain judgments with summary reasoning.

150 In that case, the Estonian Supreme Court refused to examine the appeal on points of law because the Court of Appeal's decision had been final and not amenable to appeal. It nevertheless stated that, according to the established case law, in settlement proceedings the court should not limit itself to merely analysing the settlement reached but must also verify whether there were still questions that should be addressed in the subsequent judgment yet had not been included in the settlement agreement. See Leuska v. Estonia, No. 64734/11, 7.11.2017, para. 22.

151 It found that the complaints raised in that case did not justify an examination in cassation proceedings and, in a statement based on Section 80a of the Judiciary (Organisation) Act, declared the appeal in cassation inadmissible. Nevertheless, it stated in addition that it is inherent therein that the request contained in the written grounds of appeal to put a preliminary question to the CJEU must not be granted. The Supreme Court went on to give reasons for that in saying that such a judgment as the one at hand, with abridged reasoning, contains the conclusion that no issues arise that justify an examination in cassation proceedings or give rise to the need for a determination of issues in the interests of legal uniformity, legal development, or legal protection. According to the Supreme Court of the Netherlands, since preliminary questions within the meaning of Article 267 of the TFEU involve the interpretation of EU law and are issues of law, it is inherent in such a judgment that there is no need to set forth preliminary questions. The Supreme Court added that this judgment also implies that the case in question encompasses one of the situations wherein there is no need for such referral of preliminary questions and cited the grounds listed in the C.I.L.F.I.T. case law of the CJEU. See Baydar v. the Netherlands, No. 55385/14, 28.4.2018, para. 20.

152 See Baydar v. the Netherlands, No. 55385/14, 28.4.2018, para. 48. 
As seen in the ECtHR judgment in Baydar $v$. the Netherlands, the bill that introduced summary judgments in cases of accelerated-procedure inadmissibility was intended to enable the Supreme Court of the Netherlands to concentrate on its core tasks as a court of cassation. According to the explanatory memorandum on this bill, the adequate execution of the core tasks of the Supreme Court is under pressure as a result of cassation appeals being lodged in cases that do not lend themselves to a review in cassation, and because certain issues about which it would be desirable for the Supreme Court itself to pronounce do not reach the Supreme Court in time, or at all. The Strasbourg Court in its judgment in Baydar v. the Netherlands accepted that, in line with the aim of the legislature, the relevant Dutch laws are aimed at keeping the length of proceedings reasonable and also allow courts of cassation or similar judicial bodies to concentrate efficiently on their core tasks, such as ensuring the uniform application and correct interpretation of the law.

The need for efficiency of the court should not outweigh the need to give reasons. However, the overall efficiency of a court in handling the cases is also of importance from the point of view of those seeking justice: their cases will be decided more quickly if there is no benefit of a detailed judgment; they receive an answer quickly and can go on with their lives. It is important that they understand the reasons for there being limited reasons for certain decisions that the courts make, and they need to know and acknowledge that the superior courts with their summary judgments have in a sense agreed with the reasoning of lower courts. The supreme courts in turn can concentrate on important problematics if they are after all courts of cassation, not revision.

In relation to the Luxembourg Court there could easily be discussions about creating a certain filtering system as well. In the Strasbourg Court it exists to a certain extent in examining of the so-called singlejudge cases: the single judge effectuates a filter. Nevertheless this is not comparable to the so-called leaveto-appeal system of the Supreme Court of Estonia, as in the Strasbourg Court the criteria for filtering are limited mostly to filtering out the cases that have failed to meet the criteria necessary for turning to the Strasbourg Court, such as applications out of ratione materiae, temporis, or personae; cases that are premature and still pending before domestic courts; and applications that do not comply with the six-month time limit or terms on exhaustion of domestic remedies. The Strasbourg Court can also declare an application inadmissible if it would otherwise (by deciding the case) act as a fourth-instance court. Instead, the Supreme Court of Estonia has a well-developed leave-to-appeal system. The European Commission of Human Rights has found inadmissible an application that asked for reasoning for the Estonian Supreme Court's refusal to grant leave to appeal; the ECtHR has implicitly accepted the leave-to-appeal system in the Estonian Supreme Court. What is important is that the summary judgment should not be arbitrary or otherwise manifestly unreasonable. The Baydar case law of the ECtHR could be seen as an answer to the Estonian dilemma - it does not at first sight necessarily mean a need for a change in the leave-to-appeal system in the Estonian Supreme Court, although it is always preferable to give reasons, at least stating agreement with a lower court's reasoning. One perhaps wise piece of advice to the Estonian Supreme Court would be to explain, similarly to the Supreme Court of the Netherlands, exceptionally in one refusal of leave to appeal, that the general requirements for granting leave to appeal also cover the situation of preliminary questions to the CJEU and C.I.L.F.I.T. arguments of the CJEU.

However, the further developments of Strasbourg case law should not be neglected and must be followed. It is also to be noted that the cases have dealt with preliminary references related to the interpretation of EU law and not the issues of validity of EU law.

So far, the Estonian courts have made reasonable use of the preliminary reference procedure before the Luxembourg Court. They should continue to be active also in explaining to litigants the need / lack of need and the meaning of a possible reference to the CJEU and should show well the reasoning for a decision of non-referral, so that the Supreme Court can, if need be and if applicable, make a final decision in its habitual summary judgment. 